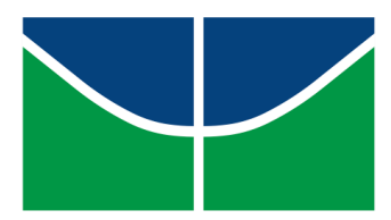

Universidade de Brasília

Faculdade de Economia, Administração, Contabilidade e Gestão de Políticas Públicas - FACE

Programa de Pós-Graduação em Economia - PPGECO

Mestrado em Economia

A POLÍTICA ECONÔMICA DO MICROCRÉDITO NO BRASIL: UM ESTUDO SOBRE O CREDIAMIGO NO BANCO DO NORDESTE COMO FORMA DE INCLUSÃO SOCIAL E ECONÔMICA

Elizaneide Almeida de Lima

Brasília-DF 


\section{A Política Econômica do Microcrédito no Brasil: Um estudo sobre o CrediAmigo no Banco do Nordeste como forma de inclusão social e econômica}

Dissertação apresentada ao Departamento de Economia da Faculdade de Economia, Administração, Contabilidade (FACE) da Universidade de Brasília como requisito parcial para obtenção do título de Mestre em Economia.

Área de concentração: Economia do Setor Público.

Orientador: Prof. Dr. Antônio Júnior

Brasília-DF 

CrediAmigo no Banco do Nordeste como forma de inclusão social e econômica

\section{Avaliação \\ BANCA EXAMINADORA}

Prof. Dr. Antônio do Nascimento Junior, UnB, Orientador.

Professor Dr. Roberto de Goes Ellery Junior, Membro interno.

Professor Dr. Geraldo Sardinha Almeida, UnB Membro externo.

Brasília - DF, de 16 de setembro de 2016 


\section{AGRADECIMENTOS}

Início meus agradecimentos primeiramente à Deus, já que Ele colocou pessoas tão especiais em minha vida, sem as quais certamente não teria dado conta!

A meu esposo, Santino Barbosa, meu infinito agradecimento. Sempre acreditou em minha capacidade e sempre me achou A MELHOR de todas, mesmo não sendo. Isso só me fortaleceu e me fez tentar não ser A MELHOR, mas a fazer o melhor de mim.

Obrigada pelo amor e carinho dedicado a mim, obrigada por ser tão importante em minha vida, sempre estando ao meu lado, me pondo para cima e me fazendo acreditar que posso mais do que imagino.

Obrigada pelo seu companheirismo, paciência, apoio amor e amizade. Devido a tudo isso, este trabalho pôde ser concretizado, você fez do meu sonho o nosso sonho.

A minha pequena Dandara que me acompanhou desde o início desse grande desafio me motivando a fazer o melhor sempre. Ao meu guerreirinho Bento, que me acompanhou nessa reta final me mostrando que tudo ocorrerá no tempo de Deus meus queridos filhos vocês são as maiores alegrias da minha vida. Amo vocês obrigada por me fazer uma pessoa melhor. Me esforçarei para oferecer muito orgulho a vocês.

Ao meu querido amigo Wesley, pela ajuda antes e durante todo o trabalho, obrigada pelo incentivo e apoio.

A Gildete, servidora do $\mathrm{BnB}$, que foi muito solícita na disponibilização dos dados sem os quais não seriam possíveis de analisar.

Ao meu professor Dr. Antônio Junior, por acreditar em meu potencial de uma forma a que eu não acreditava ser capaz de corresponder. Sempre disponível e disposto a ajudar, querendo que eu aproveitasse cada segundo para absorver algum tipo de conhecimento. Faz-me enxergar que existe muito mais que pesquisadores e resultados por trás de uma dissertação, mas vidas humanas. Obrigada por acreditar em mim!

A meus amigos do mestrado, pelos momentos divididos juntos, especialmente a Fabi, Stelinha e André que tornaram mais leve nossas quintas e sextas feiras quinzenais. Obrigada por dividir comigo as angústias e alegrias e ouvirem minhas reflexões filosóficas. Foi bom poder contar com vocês!

As minhas queridas amigas, Amada, Alê, Lúcia e Patricia, vocês estiveram ao meu lado nesses últimos dois anos compartilhando sonhos, alegrias e tristezas, mas sempre motivando umas às outras, enfim estamos sempre ligados pelas nossas princesas Clarinha, Belinha Valentina e Julinha. Amo vocês 
Às servidoras da UNB Dani e Josivane, pela disponibilidade, simpatia e gentileza.

Por fim gostaria de agradecer a minha cunhada Jussara, que esteve todo esse tempo cuidando do meu maior tesouro.

Gostaria de agradecer também aos meus colegas do Ministério da Justiça pelo apoio durante todo este trabalho. Obrigada de coração.

"Fides, si non cogitatur, nulla est"

(A fé, sem a razão, é nula).

Santo Agostinho (354-430) 


\section{RESUMO}

A presente proposta de estudo é direcionada a caracterizar o microcrédito como um instrumento capaz de promover o desenvolvimento social de maneira que seja possível analisar as contribuições como forma de inclusão social e econômica do microcrédito especialmente por meio do CrediAmigo como política de microcrédito do Banco do Nordeste - BNB. Por conseguinte, destacaremos o microcrédito como instrumento principal das microfinanças. Por meio de estudos doutrinário que conceitua o microcrédito como uma metodologia de financiamento com formas próprias de garantia e identificar, nessa metodologia, uma capacidade de atingir as pessoas socialmente excluídas do mercado financeiro formal de modo a promover sua inclusão econômico-social. Por meio de estudo da legislação brasileira, será possível conhecer melhor o seu funcionamento destacando algumas instituições que trabalham com o sistema de microcrédito no País: suas fontes de financiamento. Conclui que o microcrédito é o instrumento central de uma economia focada no ser humano e que tem como objetivo a inclusão e o desenvolvimento social. Portanto, o seu fomento pode ser considerado uma estratégia importante para reduzir a desigualdade social e para erradicar a pobreza no Brasil.

Palavras-chave: Desenvolvimento social. Microcrédito. Governo Federal. Microcrédito do Banco do Nordeste. 


\begin{abstract}
The proposed study is directed to characterize microcredit as a tool to promote social development so that it is possible to analyze the contributions as a form of social and economic inclusion of microcredit especially through CrediAmigo as microcredit policy of Banco do Nordeste - BNB. Therefore, we will highlight microcredit as the main instrument of microfinance. Through doctrinal studies conceptualizing microfinance as a financing method with their own forms of guarantee and to identify, in this methodology, an ability to reach the socially excluded from the formal financial market in order to promote their economic and social inclusion. Through study of Brazilian law, you can better understand its operation highlighting some institutions that work with micro-credit system in the country: its sources of funding. It concludes that microcredit is the central instrument of a focused economy in the human being and aims at inclusion and social development. Therefore, its development can be considered an important strategy to reduce social inequalities and to eradicate poverty in Brazil.
\end{abstract}

Keywords: Social development. Microcredit. Federal government. Microcredit Banco do

Nordeste. 


\section{LISTA DE TABELAS}

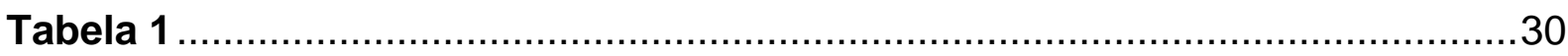

Tabela 2

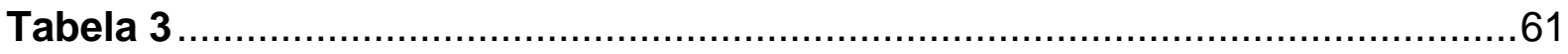

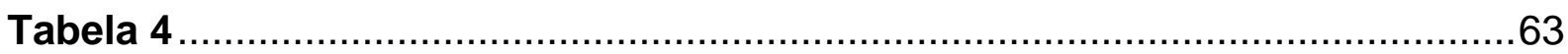

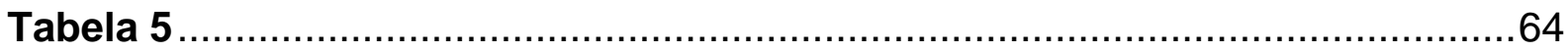

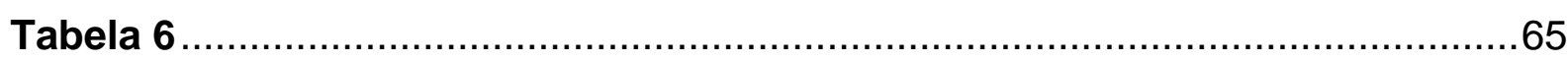

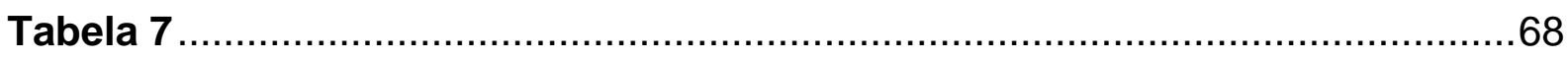

Tabela 8

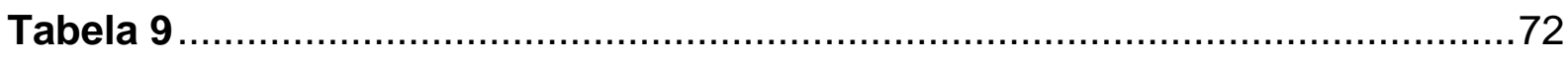

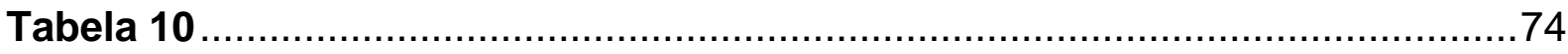

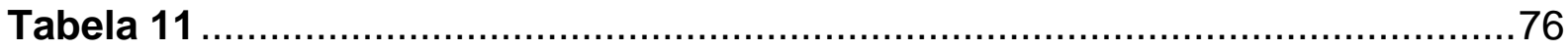

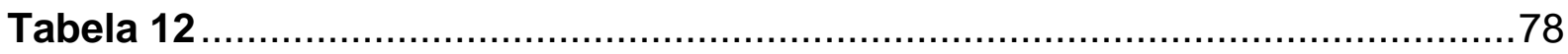

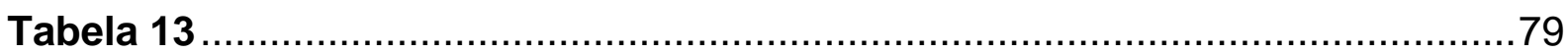




\section{LISTA DE GRÁFICOS}

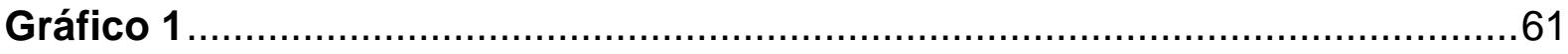

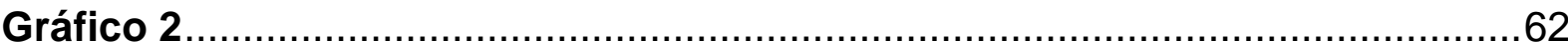

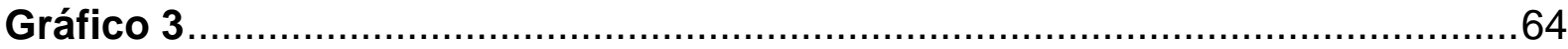

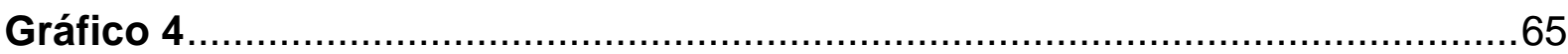

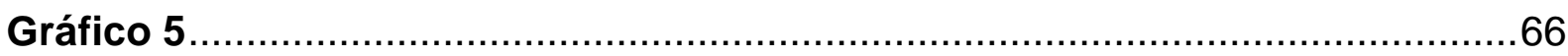

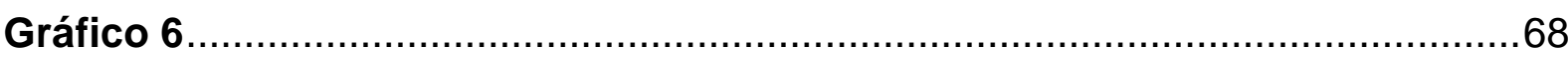

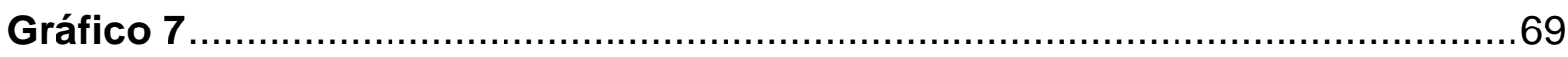

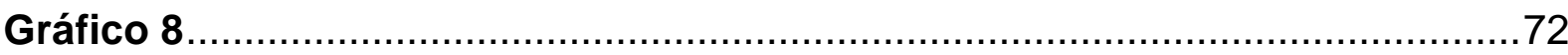

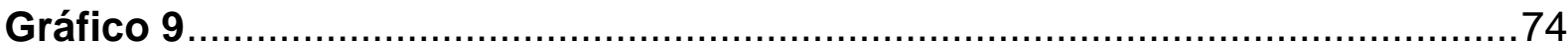

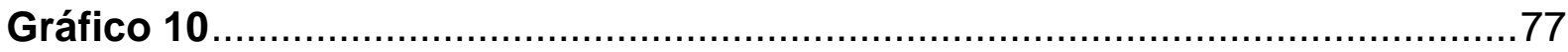

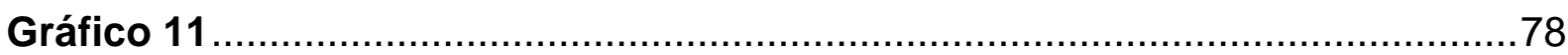

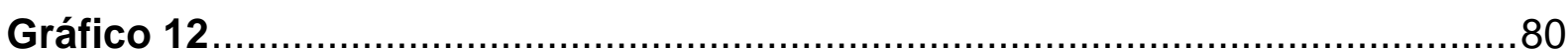




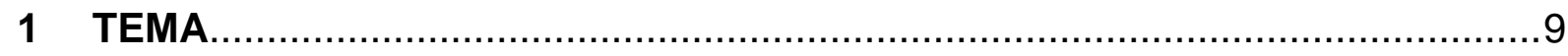

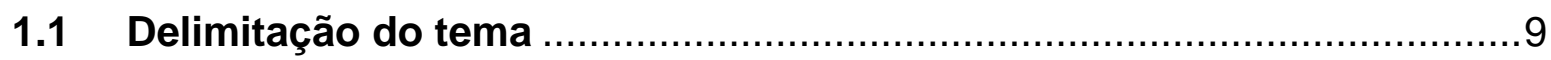

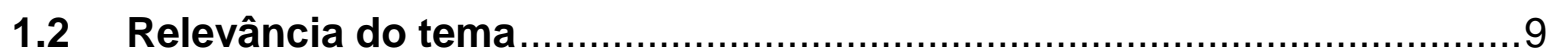

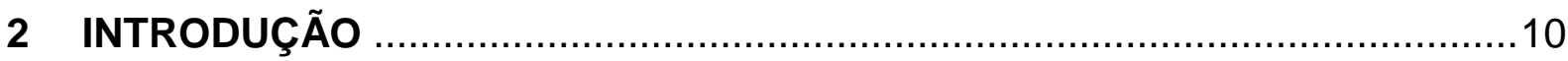

2.1 Caracterização e Definição do Problema .......................................15

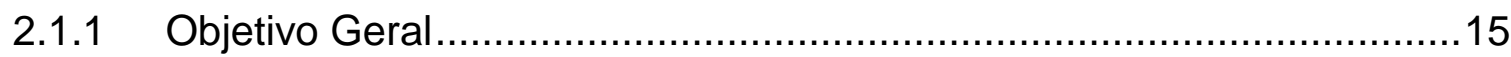

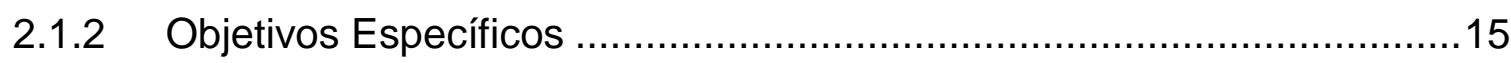

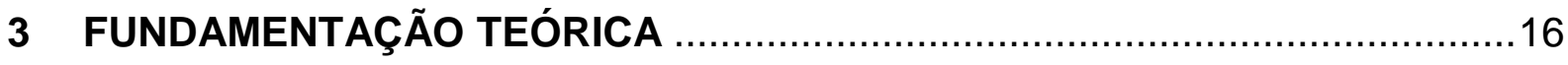

3.1 Política de Microcrédito no Mundo ................................................. 16

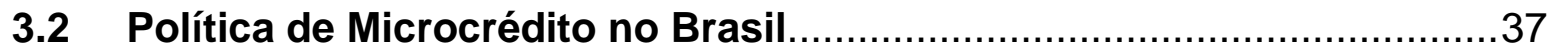

3.3 Política de Microcrédito do Governo Federal ....................................43

3.4 Política de Microcrédito do Banco do Nordete - BNB ….....................53

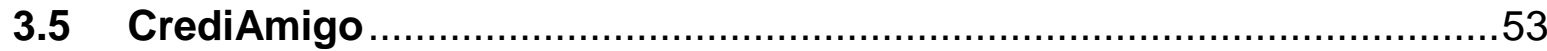

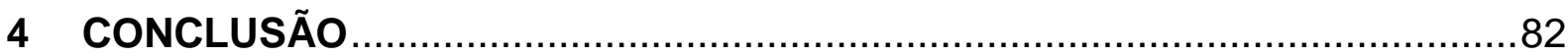

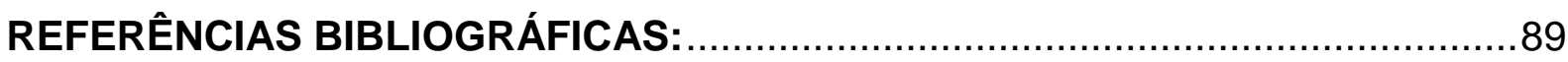




\section{TEMA}

Uma análise sobre a Política Econômica do Microcrédito no Brasil: Um estudo sobre o CrediAmigo no Banco do Nordeste como forma de inclusão social e econômica

\subsection{Delimitação do tema}

O estudo será direcionado às políticas de microcrédito realizadas no Brasil especificamente sobre o CrediAmigo, por meio do Banco do Nordeste - BNB, e pelas políticas de microcrédito como política pública nos governos de 2000 a 2010 explanando com a criação do Plano Nacional ed Microcrédito Produtivo Orientado PNMPO fazendo um paralelo com as políticas do Banco Grameen da Índia.

\subsection{Relevância do tema}

O estudo é relevante para a conscientização dos governantes e da sociedade como um todo, no sentido que buscar apresentar um estudo substancial sobre a importância da inclusão e da acessibilidade social e econômica. A fim de contribuir com ações esclarecedoras sobre o tema. 


\section{INTRODUÇÃO}

O acesso ao crédito como um direito fundamental da pessoa humana, na medida em que the garante igualdade de oportunidades, melhora suas condições de vida e de trabalho e garante o desenvolvimento econômico e social do País. Nesse sentido, garantir o direito de acesso ao crédito surge como um dos principais elementos para a consecução dos objetivos constitucionais brasileiros.

Diante disso, o Programa de crédito Microcrédito do Governo Federal é destinado a atender as necessidades de empreendedores de baixa renda para apoiar as atividades produtivas de micro e pequenos empreendedores de todo o país, para abrirem ou ampliarem seus negócios, ou seja, os recursos adquiridos por meio do microcrédito podem ser usados como capital de giro, para expandir e aquecer os negócios, para criar equilíbrio de caixa, entre outras finalidades.

Ademais, para justificar o Programa Nacional de Microcrédito como política econômica em prol de garantir o acesso ao crédito a todos como forma de inclusão social e ter elementos que comprovem a sua eficiência de maneira que se alinhem ao fomento e ao desenvolvimento regional e erradicação da pobreza.

Como motivação inicial, esse trabalho será tratado sob o aspecto de duas visões inclusivas do capitalismo: uma econômica, e outra, social.

$\mathrm{Na}$ primeira, a econômica, o Professor indiano C.K. Prahalad (2005) evidencia a riqueza que se encontra relativamente inexplorada nas camadas mais pobres da sociedade e apresenta questões a serem observadas pelas empresas que pretendam explorá-las. Trata-se de uma visão econômica, pois estuda a base da pirâmide socioeconômica em uma posição passiva e apresenta-a como um mercado a ser explorado.

Na segunda, a social, tem-se o ganhador do Prêmio Nobel da Paz de 2006. Muhammad Yunus (2006), com seu Grameen Bank, propõe uma posição mais ativa dos mais pobres e coloca-os no centro da exploração dessa riqueza, gerando o desenvolvimento a partir de baixo. O Professor Yunus difundiu no mundo a ideia do microcrédito e dos benefícios que sua implementação traz para a economia mundial. 
Nesse sentido, estudaremos, então, algumas políticas de microcrédito e analisaremos a sua adequação à legislação nacional.

A pretensão deste trabalho também será de abordar e discutir algumas das visões sobre a questão da pobreza no mundo, e apresentar o microcrédito como uma das soluções possíveis. Isso será feito através do estudo das formas organizacionais do segmento no Brasil, das posturas e relações dos três setores da economia com o sistema de microcrédito.

Para falarmos sobre tudo isso citado acima é importante falar de um modo geral sobre o processo da globalização. Com esse processo ocorreram várias mudanças no cenário econômico e político e isso fez com que muitas empresas passassem por processos vitais reformulando suas atividades como forma de sua sobrevivência no mercado.

Tudo isso gerou também uma exigência maior na contratação de mão de obra qualificada para desemprenhar certas funções específicas. Nessa casião, muitos trabalhadores perderam seus empregos, visto que não tinham a qualificação exigida diante do processo de mudança e com isso muitos entraram no mercado informal ou pelo menos tentaram. E todo esse cenário de certa forma contribuiu ainda mais para a inacessibilidade ao crédito no sistema financeiro tradicional com o aumento do desemprego.

Sabe-se que existem diversas pessoas que não possuem acesso ao mercado financeiro, no entanto, ainda existem poucas iniciativas por parte das instituições governamentais no sentido de se criar políticas de acessibilidades voltadas para essa população que sofre com vários tipos de mazelas. Aqui é importante ressaltar que as atuais iniciativas existentes por parte do governo brasileiro no intuito de contribuir com as políticas de microcrédito têm colaborado com ações voltadas para a população de baixa renda, porém ainda não são capazes de atingir e sanar de maneira eficiente os problemas enfrentados por essa parcela da sociedade.

Para isso, seriam necessárias políticas que se objetivam dar acessibilidade para grupos específicos com o intuído de diminuir as desigualdades sociais e econômicas predominantes em nosso país. $E$ isso requer investimentos com 0 
objetivo de diminuir a pobreza, implementando ações para o pequeno e microempreendedor no intuído do crescimento e fortalecimento dessas ações, assim como o estímulo para a criação de instituições que realmente fiscalizem esses programas.

Deste modo, as políticas de microcrédito podem ser vistas não somente associadas a temas relacionados à parte econômica ou de uma ação assistencialista, mas podem ser implementadas e abordadas como um programa de governo de maneira a refletir nas políticas de caráter social e não necessariamente de caráter assistencialista.

É importante ressaltar que sem a implementação dessas políticas pode-se agravar uma crise de desemprego severo em nosso país e excluir ainda mais o que não possuem acesso ao crédito.

A revolução no pensamento econômico, no século passado segundo Keynes, revelou que a determinação do nível de emprego não depende de decisões dos trabalhadores. A economia capitalista não consegue empregar, continuamente todos aqueles que desejam trabalhar.

Ainda segundo ele, existe o desemprego quando o impulso para os gastos em investimento dos contratantes de mão de obra não é suficiente para justificar a contratação de toda a população economicamente ativa que busca emprego.

Nesse ponto, poderíamos fazer uma reflexão no sentido de questionar quais iniciativas poderiam ser feitas por parte dos governantes para tentar de alguma forma alavancar a economia no combate a esses fatores.

Alguns autores afirmam que a lógica do sistema capitalista requer que o poder de compra não seja meramente estendido a qualquer um que deseja ter crédito. Os grandes investimentos geralmente são concedidos somente àqueles que praticamente reembolsam os bancos.

Todavia, o pequeno e o microempreendedor não têm o mesmo acesso que os grandes investidores possuem e nem o poder de barganha e por sua vez ficam a 
margem do mercado informal por meio dos agiotas agravando ainda mais a situação.

Em um cenário de instabilidade política, ética e econômica um dos grandes diferenciais entre as grandes empresas e o pequeno e microempreendedor é que as grandes empresas além de serem subsidiada e de contarem com a tecnologia sofrem menos com os impactos de um mercado em crise. $O$ micro e pequeno empreendedor por sua vez seriam a parte mais fraca, pois existem poucas ações no sentido de custear esses empreendedores por isso se faz necessária a criação de ações orientadas ao desenvolvido desses trabalhadores e de combater a pobreza. Isso evitaria que fechassem as portas dos seus pequenos negócios evitando também que se tornem mais um desempregado no mercado de trabalho.

Logo, é necessária a intervenção do Estado no sentido de proporcionar uma maior acessibilidade, sobretudo às políticas de microcrédito de forma orientada de maneira a permitir a inclusão social e econômica, como ocorre em outros países.

Pois, com o perceptível aumento da velocidade das mudanças e da ocorrência, aliados ao número de informações propiciam às empresas uma enorme pressão que as obriga a elevar seus níveis de produção o que faz com que busquem nos mercados profissionais qualificados para atenderam a demandas dos consumidores que estão cada vez mais exigentes. E na sua ausência deixam de contratar aumentando ainda mais o desemprego.

Por conseguinte, sem o auxílio do Estado, alguns trabalhadores que não encontram no mercado formal iniciativas e oportunidades de emprego ficam cada vez mais excluídos desses mercados capitalistas globalizados, e começam a passar por grandes dificuldades de empregabilidade.

Com tudo isso, esses trabalhadores com pouca experiência acabam por montar o seu próprio negócio sem nenhuma orientação e passam a trabalhar por conta própria em busca de melhores condições de vida e se tornam micro e pequeno empreendedor.

Assim, o estudo ora apresentado, tem como temática estudar e conhecer as políticas de microcrédito, especificamente as políticas implementadas pelo Banco do 
Nordeste - BNB, que atualmente é a mais bem-sucedida experiência sobre o microcrédito no Brasil, e as políticas de microcrédito como política pública no Governo Federal.

Sei que trarão muitos benefícios sobre um tema tão relevante como este, visto que apresenta muitas vantagens não só para os governantes, mas também para a sociedade como um todo.

Deste modo, este trabalho corrobora para uma maior divulgação de políticas desconhecidas para vários segmentos do mercado e para a maioria da população brasileira. 


\subsection{Caracterização e Definição do Problema}

Considerando, a proposta de estudo sobre as políticas do microcrédito, enquanto ferramenta de geração de renda e redução de pobreza apresenta-se a seguir o problema da pesquisa: realizar uma análise descritiva do CrediAmigo em uma década.

\section{Objetivos}

\subsubsection{Objetivo Geral}

Realizar uma análise descritiva da Política de Microcrédito do Programa CrediAmigo nos anos de 2000 a 2010.

\subsubsection{Objetivos Específicos}

- Descrever o histórico do microcrédito no mundo;

- Descrever o histórico do microcrédito no Brasil;

- Pesquisar a política econômica do microcrédito dentro da estrutura do Governo Brasileiro;

- Apresentar a Política de Microcrédito do Banco do Nordeste - BNB, por meio do CrediAmigo;

- Mostrar como essas ações refletem no crescimento econômico e na inclusão social. 


\section{FUNDAMENTAÇÃO TEÓRICA}

No referencial serão apresentadas as fundamentações teóricas sobre a política de microcrédito no mundo e microcrédito no Brasil, envolvendo características, conceitos, atividades desenvolvidas no mundo e no Brasil e como isso é refletido na sociedade.

\subsection{Política de Microcrédito no Mundo}

Existem registros históricos de que a primeira vez que se tenha mencionado sobre a política de microcrédito foi quando no sul da Alemanha em 1846, foi criada uma associação do pão, pelo religioso Raiffeinsen, que concedia farinha de trigo aos camponeses endividados com agiotas para que os camponeses pudessem aumentar a sua renda com a fabricação e a comercialização de pães. Todavia, essas práticas ocorreram de forma isolada.

Por conseguinte, estudos mostram que desde o século XIX, já havia em diversos países assim como na Europa exemplos de política de microcrédito. Entretanto, a política de microcrédito mais conhecida e utilizada no mundo de combate à pobreza que vem influenciando vários países aconteceu na década de 1970, em Bangladesh (SANTIAGO, 2014; REYMÃO e CORRÊA, 2014).

Antes de tratarmos mais profundamente sobre as políticas de microcrédito da Índia, vamos abordar algumas diferenças entre microcrédito e microfinanças, visto que tanto no mundo acadêmico quanto no político ainda se apresenta de maneira confusa em discursos a respeito desses temas.

Micro, segundo o Dicionário Aurélio da Língua Portuguesa (FERREIRA, 1986, p. 1131), é um prefixo de origem linguística grega (mikrós) que, quando anteposto ao substantivo, adjetiva-o como "pequeno", "curto", "fraco", etc., tornando seu valor lógico relativamente menor ao valor lógico do substantivo tomado isoladamente. 
Ainda segundo Ferreira, crédito, é um substantivo com origem no latim (creditu), que, dentre seus diversos e possíveis significados, encontra-se a "soma posta à disposição de alguém num banco, numa casa de comércio, etc., mediante certas vantagens".

$\mathrm{Na}$ Cartilha do Microcrédito, produzida nas Rodadas de Interlocução Política sobre o Microcrédito, promovidas pela Comunidade Solidária, Francisco Marcelo Barone e outros (2002), assim definiram microcrédito:

[Microcrédito é] a concessão de empréstimos de baixo valor a pequenos empreendedores informais e microempresas sem acesso ao sistema financeiro tradicional, principalmente por não terem como oferecer garantias reais. É um crédito destinado à produção (capital de giro e investimento) e é concedido com o uso de metodologia específica (BARONE, LIMA, DANTAS, REZENDE, 2002, p. 11).

Para alguns autores as microfinanças por sua vez, define-se como um campo da economia no qual se combinam mecanismos de mercado, apoio estratégico do Estado e iniciativas comunitárias com o objetivo de estruturar serviços financeiros sustentáveis para a clientela de baixa renda, sejam indivíduos, famílias ou empresas (formais e informais).

C. K.( Prahalad 2005), destaca que:

a distribuição da riqueza e a capacidade de geração de renda podem ser entendidas sob a forma de uma pirâmide econômica. No topo da pirâmide estão os ricos, com numerosas oportunidades de gerar altos níveis de renda. Mais de 4 bilhões de pessoas vivem na BP6, com menos de US\$2 por dia (PRAHALAD, 2005, p. 18).

$\mathrm{O}$ autor ainda menciona que quando se deixa de pensar nos pobres como vítimas ou como um fardo e começarmos a reconhecê-los como empreendedores em um mundo novo de oportunidades poderá se abrir.

Nesse sentido, o microcrédito disponibiliza um tipo de serviço diferenciado no sistema financeiro, como por exemplo as concessões de empréstimo de uma forma diferenciada das linhas de crédito tradicionais poderiam falar que o microcrédito está no campo micro, enquanto as microfinanças estão em um campo Macro, visto que este disponibiliza diversos serviços organizacionais e financeiros e não se limita 
necessariamente ao dinheiro, hoje ele é um meio que inclui diversos tipos de serviços. É importante fazer essa diferenciação, visto que na prática eles operam de maneiras diferentes.

Voltando ao microcrédito na Índia, que vem contribuindo com a mudança de vida da população de Bangladesh, especialmente a vida das famílias de baixa renda: Yunus afirma que

O crédito por si só, não poderia acabar com a situação de pobreza. Ele é apenas um dos meios que permitem sair da pobreza. Outras saídas podem ser abertas para facilitar a mudança. Mas para isso é necessário ver as pessoas de modo diferente e conceber um novo quadro para essa sociedade, coerente com essa nova visão (YUNUS, 2006, p. 9).

Segundo Franco de Matos, avaliar a pobreza por meio de crédito subsidiado fez parte da estratégia de desenvolvimento da maioria dos países no início dos anos 50 sem grande sucesso, pois a lógica assistencialista desses programas rapidamente consumia suas carteiras. Além disso a intervenção governamental, muitas vezes passível de corrupção, provoca descrédito nesse tipo de política.

O autor ainda acrescenta que o sistema de microcrédito adotado pelo Banco Gremeen de certa maneira entra como um sistema financiador totalmente diferente dos sistemas assistencialistas propostos até então.

Dessa maneira, fica fácil entender porque a política de microcrédito da índia é reconhecida como idealizadora do microcrédito pelo mundo, pois antes da década de 70 não existia formalmente o termo microcrédito.

De acordo com Yunus; Jolis (2000, p. 23):

Infelizmente não havia nenhuma instituição financeira capaz de satisfazer as necessidades dos pobres em matéria de crédito. Esse mercado do crédito, na ausência de instituições oficiais, fora açambarcado pelos agiotas locais, que sempre levavam seus "clientes" a se embrenhar mais fundo na estrada da pobreza.

Além de vários outros problemas enfrentados pela população de Bangladesh, historicamente os estudos nos mostram que em 1970, a cidade de Bangladesh, passava por uma onda muito forte de fome e por uma série devastadora de desastres naturais que causavam muitas inundações e muitas secas. 
Há época as políticas adotadas por parte dos governantes, assim como em outros países atuavam de maneira desorganizadas e por mais que recebessem recursos financeiros pela comunidade internacional, esses recursos não eram suficientes, tendo em vista que a desigualdade local era muito exorbitante e nem todos eram contemplados com essas políticas.

E como se não bastassem todas essas tragédias conforme vários relatos históricos, a população ainda passava pela grande crise do petróleo de 1973.

Todos os países são suscetíveis há passar por alguma crise seja em escala maior ou menor, e quase sempre quando isso ocorre fica mais fácil a percepção da desigualdade social, em tempos de crise toda a população sofre, ninguém fica imunes da crise, assim imagina-se que as dificuldades passadas por todos eram enormes, em especial os mais pobres.

Segundo o Banco Internacional de Desenvolvimento (1999), a América Latina é a região com a distribuição de renda mais desigual em todo mundo.

Alguns autores acreditam que por meio das políticas desenvolvidas pelo microcrédito será possível diminuir um pouco essa desigualdade.

Após observar todos esses acontecimentos, e conversar com uma das mulheres da aldeia que era artesã, Yunus(2008) conseguiu entender o motivo pelo qual a população carente de Jobra, continuava naquela situação.

Conforme relatos no livro Um mundo sem pobreza (2008, p. 59),

como muitas pessoas da aldeia, ela dependia de agiota local para obter o dinheiro necessário para comprar o vime e confeccionar seus banquinhos. Porém, o agiota somente emprestava dinheiro se Sufiya concordasse em vender-lhe tudo o que produzisse a um preço estabelecido por ele"

Nessa perspectiva, é fácil compreender que alguém que consiga dinheiro nessas condições a juros altíssimos e em contrapartida sem opção de venda, fica impossível sair da extrema pobreza.

De porte dessas informações, em Bangladesh foi realizada uma pesquisa por meio de visitas porta a porta, nas casas das famílias de baixa renda que 
trabalhavam por conta própria por categorias como: artesãos e marceneiros por exemplo, essas pessoas para conseguirem realizar suas atividades necessitavam de dinheiro para comprar matéria prima, porém em razão de sua condição financeira por não terem como comprovar a sua renda eles não tinham acesso às linhas de credito tradicionais.

A pesquisa realizada contou com a participação de quarenta e duas famílias que se encontravam nas mesmas condições que a artesã mencionada anteriormente na pesquisa "que esses artesãos tinham pegado um total de 856 tacas e a época equivalia a 27 dólares americanos". Ou seja, com esse processo de pegar empréstimos com juros exorbitantes dificultava ainda mais a vida desses pequenos empreendedores.

Após a realização da pesquisa foi revelado que várias pessoas que viviam endividados com esses empréstimos e que essas mesmas pessoas não teriam chances de terem acesso ao crédito nas linhas tradicionais para saírem dessa situação.

Segundo Janaine Lopes Pimentel, as pessoas que estão à margem do sistema financeiro por não serem capazes de comprovar capacidade financeira, garantias reais e, em muitos casos por não estarem legalmente constituídas, restam aos investidores de microempreendimentos e aos trabalhadores autônomos recorre a um "sistema financeiro paralelo" operado por agiotas que atuam a margem da legalidade, perpetuando as desigualdades e limitando o crescimento econômico das pessoas que recorrem a esse tipo de crédito.

Já o autor Mazzutti (2005) diz que algumas pessoas até possuem algum tipo de garantia, porém o valor que esses bens possuem é de baixo valor de mercado e de certa maneira por conta disso não são aceitas como garantias.

Destarte, Yunus (2010, p. 24) teve a ideia de emprestar dinheiro para com a intenção de liberta essas pessoas dos agiotas. Essa era uma maneira de tentar financiar os mais pobres que não tinha acesso aos bancos por não enxergarem naquela população potenciais clientes, pelo simples fato de não apresentarem garantias. Ou seja, toda essa situação de certa forma contribui para a formação de 
um sistema financeiro paralelo que por sua vez faz com que diversas famílias reclusas a esse sistema façam empréstimos a juros altíssimos utilizando outros meios.

Pois, por meio de ações como essa é possível interferir de certa maneira na economia de maneira a gerar um impacto social e econômico por meio da disponibilização de acesso ao crédito permitindo que pequenos empreendedores a dessem a seu negócio ou ampliando os negócios já existentes permitindo, assim a geração de emprego e renda.

Todavia, se analisarmos de maneira geral , toda instituição financeira é capaz de fornecer crédito a essas pessoas, porém quando se trata de disponibilizar o acesso ao crédito as pessoas de baixa renda, o discurso é sempre bem refinado para não empestar dinheiro a essas pessoas, pois alegam que além da falta de garantias reais, ainda argumentavam que a grande maioria daqueles que precisavam de crédito são analfabetos o que contraria totalmente os princípios intitulados pelos banqueiros mesmo que fossem baixas quantias e levando em consideração que essas pessoas não possuem garantias.

Contudo, diante do potencial de crescimento pelas políticas de microcrédito, levando em consideração que existe um público totalmente carente que necessita de possibilidades para terem acesso a essa linha de credito, acredita-se que essa é uma ação que possui um potencial muito grande de crescimento. E que possibilita o empoderamento das pessoas de baixa renda.

Movido, então pelo objetivo de auxiliar as pessoas de baixa renda, que não tinham acesso aos bancos o "banqueiro dos pobres", como é conhecido, ficou durante muito tempo agindo como fiador daquela população que de certa maneira não eram assistidas pelas linhas tradicionais de crédito, assim, ele pegava dinheiro emprestado aos bancos e emprestava o mesmo dinheiro aos pobres, que ao final honrava fielmente com os pagamentos. Contudo, mesmo com essas ações e horando os pagamentos a visão dos banqueiros em emprestar dinheiro aos pobres não mudou. 
"Com a iniciativa e experiência em emprestar dinheiro a pequenos grupos o microcrédito tornou-se popular em 1976, e assim nasceu o Banco Grameen que é um tipo especial de banco que empresta aos mais pobres sem qualquer lucro" e tinha como objetivo de pôr fim à pobreza por acreditar que é essa seria uma excelente estratégia de combate à pobreza por proporcionar muitos benefícios as pessoas de baixa renda.

Assim, podemos entender que o grande objetivo do Grameen é pôr fim a pobreza, acreditando nessa filosofia o banco oferece empréstimos a pequenos grupos solidários formados por 5 pessoas, seus componentes são principalmente formados por mulheres por acreditar que as mulheres, devedoras prioritárias, tornam-se as maiores responsáveis pelas finanças domésticas.

Autores como Matos e outros, justificam que a concessão de microcrédito no Grameen foi focalizada preferencialmente nas mulheres, justamente pelo fato de acreditarem que elas são mais responsáveis em investir a renda na família e não para uso pessoal, além de ampliar os ganhos sociais da política também são reconhecidas por serem melhores pagadoras do que os homens.

Aqui, percebe-se que as experiências internacionais de políticas de microcrédito diferenciam-se das políticas adotadas no Brasil, por exemplo, principalmente em relação ao gênero, visto que como na implementação, inclusive do CrediAmigo o público mais atendido era do gênero masculino, sendo essa realidade foi mudada no terceiro ano. Na índia desde o início são voltadas para mulheres. Nessa experiência realizada em Bangladesh, é demostrado que as mulheres são melhores pagadoras do que os homens e mais responsáveis em investir a renda na família e não para uso pessoal.

Assim, a política de microcrédito no mundo pode ser definida como uma revolução no pensamento econômico, no limiar do novo século, impulsionada pelo Economista Muhammad Yunus (2010).

a pobreza não apenas condena os seres humanos a uma vida de dificuldades e infelicidade, como também pode expô-los a perigos que ameacem sua vida. Uma vez que a pobreza nega às pessoas qualquer noção de controle sobre seu destino, ela é a derradeira negação dos direitos humanos, quando a liberdade de expressão ou 
religião é violada em alguns países, as pessoas em geral reagem por meio de uma série de protestos globais. Contudo, quando a pobreza transgride os direitos humanos da metade da população mundial, a maioria de nós vira o rosto e continua vivendo.

Segundo Barone (2002,p.35):

O impacto positivo do microcrédito nas situações de pobreza é amplamente reconhecido. Ao permitir o acesso continuado ao crédito para negócios com capital próprio mínimo (razão pela qual não alcançam empréstimos junto ao sistema financeiro tradicional e pagam juros muito elevados a agiotas), fortalece o empreendimento e aumenta a renda das famílias. Desse processo, muitas vezes, resulta à volta do filho para a escola, a construção de novos cômodos na casa e a melhoria da qualidade da alimentação familiar.

Yunus esclarece que, O Prêmio Nobel da Paz, tem um significado talvez desconhecido por muitos. O Comitê lhe concedeu esse prêmio não pelas práticas e ações econômica, mas sim pela promoção da paz, justamente por colaborar com o processo da retirada de várias pessoas da pobreza.

[...] assim, a pobreza talvez seja a ameaça mais séria à paz mundial, ainda mais perigosa que o terrorismo, o fundamentalismo religioso, o ódio étnico, as rivalidades políticas ou qualquer outra força frequentemente citada como geradoras de violência e guerras. Ela conduz à desesperança, o que leva as pessoas a cometerem atos impensados. Aqueles que não possuem praticamente nada não têm nenhuma boa razão para se abster da violência, uma vez que até mesmo os atos com mínima probabilidade de virem a melhorar as condições de vida delas parecem ser melhores do que não fazer nada e aceitar o destino passivamente.

Para Soares e Melo Sobrinho (2008, p. 19),"o prêmio traduz também o reconhecimento de que dificilmente haverá paz sem que a sociedade internacional reveja e mude a estrutura econômica, de modo a diminuir a desigualdade social".

Mesmo com vários avanços nas linhas de microcrédito na Índia, sobretudo com o apoio recebido após ganhar o Prêmio Nobel da Paz, o programa de microcrédito na Índia passou ainda mais a ser referência no mundo sobre política de microcrédito, com isso o banco passou a receber muitas doações, foi aplaudido por vários economistas, mas também foi um momento em que vários críticos contrários às políticas adotadas pelo Banco Grameen se posicionassem a respeitos das dessas políticas. 
Assim, segundo o artigo do Mises Instituto, publicado em 28 de outubro de 2009, há época o único a apresentar questionamentos contrários às políticas de microcrédito publicou que:

Em 2001, os repórteres Daniel Pearl e Michael Philips, do Wall Street
Jornal, revelaram que as taxas de quitação dos empréstimos não
eram nem próximas daquelas alegadas pelo banco, que pelo menos
um quarto de seus empréstimos estava sendo utilizado para
consumo, que o banco protela seus inadimplentes e esconde seus
empréstimos problemáticos, e que o banco não está sujeito a
qualquer tipo de supervisão pública ou privada. O governo detém $6 \%$
de seus ativos, ao passo que o restante pertence aos tomadores
apenas superficialmente os tomadores de empréstimos, que não
podem vender ou trocar suas ações - o que de modo algum significa
propriedade.

Ainda de acordo com o instituto acrescentam que:

De primeira, parece uma boa ideia. Mas pense um pouco. Yunus iniciou suas operações em 1976. Trinta anos já se passaram. Se ele realmente tivesse feito uma descoberta empreendedora, será que os banqueiros convencionais a essa altura já não o estaria imitando?

Apesar de alguns autores relatarem que metade dos clientes do banco Grameen possuem seus empréstimos atrasados, e que alguns críticos afirmarem que não tem como mensurar os lucros ou prejuízos devido ao banco não está submetido à supervisão, o Banco Grameen continua apresentando um elevado alcance de eficiência e de melhoria nas condições de vida. E apesar de várias críticas as informações disponibilizadas pelo Grameen com exceção dos períodos entre 1983,1991 e 1992, revelam que ele vem apresentando lucro ao longo de sua existência.

Mesmo sendo de conhecimento esse posicionamento contrário às políticas da Índia, o Banco Mundial, apoia o microcrédito da Índia, sobretudo da Ásia e da América Latina

Outra crítica, veio do dirigente da Basis, Vijay Mahajan (2006), ainda com relação às práticas adotadas pelo Grameen alegando que elas sofrem de cinco suposições fatais:

A primeira é a ideia de que os pobres deveriam estar em empregos autônomos ao invés de estarem trabalhando por salários. Isso é 
contrário a toda a história de desenvolvimento econômico de sucesso;

A segunda é a ideia de que empréstimos são o principal serviço financeiro de que os pobres necessitam, sendo que o que eles realmente necessitam é de poupança e seguros;

A terceira é a ideia de que é o crédito que constrói o empreendimento, quando a verdade é que a iniciativa e a capacidade administrativa são mais importantes;

A quarta é a ideia de que quem não é pobre não necessita de crédito, quando a verdade é revelada pelo sistema bancário de mercado: rendas mais altas podem lidar com dívidas mais altas;

A quinta é a ideia de que instituições de microcrédito podem se tornar autossustentáveis, quando a verdade é que todas as experiências mostram que novos empreendimentos em áreas pobres baseados apenas no crédito raramente saem da dependência;

Em entrevista a David Roodman publicada pela revista Época em fevereiro de 2012, ele revelou que "o microcrédito cria pobres endividado" Assim para ele a geração de poupança e seguro ajudaria muito mais aos pobres do que a disponibilização de empréstimos fáceis.

Deste modo, o que esses críticos que são contrários às políticas de microcrédito alegam é que os programas não conseguem retirar as pessoas de baixa renda da pobreza, assim como não trazem prosperidade para essas famílias e que na verdade o que os países pobres precisariam seria de uma reforma econômica radical que venda suas empresas estatais diminuindo assim suas barreiras comerciais. E ainda acrescentam que é por meio do incentivo a poupança que ocorrem o crescimento econômico e não por meio do microcrédito.

Destarte, em 2008 em uma entrevista a revistra Trip, sobre as políticas de microcrédito como negócio, Yunus falou sobre as críticas ao seu trabalho e disse "você pode não morrer de amores por esse modelo - e eu quero discussão, quero ouvir críticas, mas não pode simplesmente dizer não funciona ou não é real" ele ainda acrescenta que: " lidar com teorias econômicas enquanto existem pessoas morrendo de fome, para ele é uma piada. "

Diante disso, as políticas implementadas se objetivam a lançar o microcrédito como instrumento de combate à pobreza de forma que se repercute nas questões 
sociais de acessibilidade, visto que nem todos possuem acesso às linhas de créditos tradicionais.

Autores como Neri (2008) e Barone (2002) nos fazem entender que apesar das críticas ao microcrédito, existem alguns casos de sucesso do microcrédito espalhados no mundo como por exemplo: Bank Rayat da Indonésia; Adopem da República Dominicana; Financeira Calpiá em El Salvador; BancoSol, Caja Los Andes, Programa de Desenvolvimento Municipal -Prodem, FIE e Dartawi na Bolívia; Caja Social na Colômbia; Compartamos no México; MiniBanco no Peru e o CrediAmigo no Brasil.

Assim, cada país conseguiu desenvolver uma política de microcrédito que de certa forma foi espelhada no modelo da Índia. Nesse sentido, podemos perceber por meio de dados históricos que cada país com suas peculiaridades conseguiu de certa maneira se espelhar no modelo da índia e implementar em seu país ajustado as necessidades locais.

Exemplo disso, podemos citar o apoio da AITEC, com a criação de várias instituições com o objetivo de fornecer o microcrédito na América Latina.

Outras ações foram realizadas pela Accion na Bolívia, com a criação da organização não governamental PRODEM, essa organização inicialmente emprestava às mulheres pequenos valores para a compra de frutas e vegetais.

A maioria delas comprava de atacadistas que traziam caminhões repletos de mercadoria de dois em dois dias". Os varejistas compravam a crédito, mas tinham que pagar na próxima vez em que o caminhão voltasse. A taxa de juros embutidas nas transações com atacadistas, era bem mais alta do que a taxa cobrada pela PRODEM. O primeiro efeito do crédito conquistado foi ajudar os vendedores a negociar com os atacadistas em posição mais vantajosa. Ao adquirir grandes quantidades de frutas e vegetais pagando à vista os varejistas a consegui melhores preços além de pagar juros menores. (RHYNE,2001 p.67-68).

Nesse ponto é importante esclarecer que assim como na Índia, apesar das políticas de microcrédito serem direcionadas aos grupos com o intuito de redução da pobreza as pessoas que são consideradas marginalizadas e de serem realmente direcionada aos pobres, não se trata de uma política de caráter assistencialista mesmo reproduzindo um impacto muito forte no aspecto social. 
Entretanto, hoje a ideia disseminada pelo Banco Gremeen é reconhecida mundialmente e em vários países e tem se tornado um instrumento muito eficaz de combate à pobreza e de inclusão social.

Se fossemos fazer uma comparação entre 0 banco dos pobres em Bangradesh, e os "bancos do povo" no Brasil ficariam fáceis identificar que, aqui é cultural mesmo já existindo pequenas ações, a grande maioria dos bancos esperarem o povo ir até suas agências, sendo que lá os agentes itinerantes do banco vão em seus domicílios, ou seja eles promovem a acessibilidade e uma relação de confiança com as pessoas de baixa renda o que não é muito comum ocorrer por aqui.

Yunus, faz de certa forma uma grande crítica aos economistas por relacionarse a diminuição de pobreza somente com empregos formais assalariados, deixando de fora em suas teorias os trabalhadores autônomos, já a filosofia do Grameen é justamente fornecer crédito a essas pessoas gerando trabalho de maneira autônoma. Pois é sabido que até o momento a economia, governos e entidades privadas não conseguem gerar emprego para todos.

Por conseguinte, a pergunta é o que os governos irão fazer com essa parcela da população mundial, visto que não conseguem empregar todos os seus cidadãos?

Será que em plena democracia e crise política e econômica essas pessoas devam ficar de braços cruzados esperando a criação de empregos formais ou será que elas teriam o direito de escolher de forma autônoma a melhor maneira de desenvolver suas habilidades contanto com a colaboração dos governos e da sociedade?

Entretanto, não é objetivo desse trabalho criticar o mercado formal, pelo contrário o emprego formal é muito importante economicamente e socialmente para todo e qualquer país, porém o que se questiona é quando ele não acontece na velocidade que seus cidadãos necessitam, quais seriam as outras possibilidades para enfrentar o problema do desemprego que poderiam ser implementados? 
Hoje em dia, apesar do Banco Grameen servir como referência de política de microcrédito em países como África, Ásia e América Latina, entre outros, ele só existe em Bangladesh.

No ano de 1997, na capital dos Estados Unidos, Washington, ocorreu a primeira reunião sobre o microcrédito. Na ocasião participaram vários países que apresentaram vários programas de microcrédito existentes no mundo. Todos no intuído da diminuição da pobreza.

[...], quase três mil delegados de 137 países, que representavam programas de microcrédito de diversos tipos e tamanhos. Juntos, foi selado o compromisso de, até 2005 , utilizar o microcrédito e outros serviços financeiros para ajudar cem milhões das famílias mais pobres do mundo (de preferência por meio das mulheres dessas famílias).

Há época foram sugeridos vários esforços, entre eles a meta em atender cem milhões de famílias. Apesar da crítica pelo fato de até o presente momento apenas 7,6 milhões de famílias serem atendidas pelas políticas de microcrédito a meta de cem milhões pareciam ser uma meta inatingível e que isso poderia simplesmente desencorajar o seu atingimento e acabar ficando para trás como tantas outras metas inatingíveis, em 2006 na reunião da Terceira Cúpula do Microcrédito realizada no Canadá na cidade de Halifax, foi anunciado o atendimento das cem milhões de famílias .

Face à literatura existente, percebe-se que as contribuições do microcrédito pelo mundo têm tirado muitas famílias da extrema linha de pobreza. Contudo, não se pode perde o conceito original do real significado do microcrédito que é justamente fornecer crédito ás pessoas pobres que não possuem acesso aos canais normais por falta de garantias reais.

Sabe-se historicamente que muitas instituições que oferecem microcrédito ignoram esse conceito e emprestam essa modalidade de crédito para pessoas que não se enquadram nesse perfil: pobre sem acesso aos canais tradicionais.

No entanto, existem hoje muitas organizações que se auto intitulam programas de "microcrédito" e oferecem empréstimos para pessoas que não são pobres, exigindo as garantias de pagamento habituais. 
Ou seja, instituições que oferece crédito exigindo garantias reais se descaracterizam totalmente do propósito das políticas de microcrédito agindo como instituições tradicionais do mercado financeiro. $E$ a grande maioria desses empréstimos acabam não gerando renda, visto que, muitos são para o consumo próprio como por exemplo compra de móveis e utensílios domésticos.

Assim, Yunus (2010), questiona em seu livro sobre o real conceito do microcrédito, por isso ele aborda dois segmentos de microcrédito segundo:

Tipo 1: Programas de microcrédito focados na pobreza, que são programas de microcrédito com foco na pobreza, sem a necessidade de garantias de pagamento e a juros baixos. O banco Gameen foi criado para essa finalidade [...] Tipo 2. Programas de microcrédito para maximização dos lucros, são programas que cobram uma taxa de juros mais alta do que a da Zona Amarela. Eles operam na Zona Vermelha, que é o território dos agiotas. [...]

Nesse ponto é até sugerido no livro Um mundo sem pobreza, que o único tipo que deveria existir de microcrédito seja o tipo 1, levando em consideração que é o único que atende ao seu proposito inicial.

Há os que sustentam que os programas de microcrédito que buscam a maximização dos lucros são verdadeiramente benéficos para os pobres e para a economia mundial em geral. Eles argumentam que as altas taxas de juros embutidas habilitam as instituições de microfinanciamento (IMFs) a tornarem-se autossustentáveis mais rapidamente. [...]

Entretanto, contrário ao posicionamento de alguns autores que acreditam que políticas do tipo 2 podem beneficiar os mais pobres argumentando que com a maximização dos lucros tornam as instituições mais autossuficientes e que atraem investidores, percebe-se que programas de microcrédito que visam lucros foge muito do proposito do microcrédito em retirar as famílias da extrema pobreza, visto que fica quase impossível ver crescimento e melhoria de vida para essas famílias cobrandoIhes altos juros. E como se sabe a maioria dos créditos disponíveis no mercado são do tipo dois, os quais reforçam esse tipo de política que fortalece as instituições de crédito e afastam aqueles que realmente precisa dele.

A literatura revela que um dos grandes problemas do financiamento de microcrédito é a falta de dinheiro nos programas de microcrédito e não a falta de 
capacidade que esse programa possui. Também é sabido que muitos países possuem esse recurso necessário para essas políticas

Nesse cenário o que poderia está faltando? Seria a mobilização dos governantes para torná-los acessível para quem realmente necessita dele?

Alguns autores, ressaltam que além do dinheiro existem outras soluções de mercado para o problema de microfinanciamento:

[...] seriam as IMFs, aceitarem depósitos de poupança- algo que as organizações de microcrédito administradas por ONGs são legalmente proibidas de fazer.

Essa solução é bem criticada no mundo das finanças, visto que não possuem uma regulamentação que autorize essas entidades a faz tais ações.

Apesar de muitos críticos alegarem que as políticas de microcrédito sozinha não resolver o problema da pobreza no mundo, sabe-se também que, essas políticas somadas a outras ações podem fortificar esse sistema a alcançar melhores resultados no combate à pobreza beneficiando milhares de famílias.

Contudo, as políticas de microcrédito não resolverem por sim só o problema da pobreza, mas podemos afirmar que ela é mais uma ferramenta que bem administrada possibilitara grandes avanços na desigualdade social.

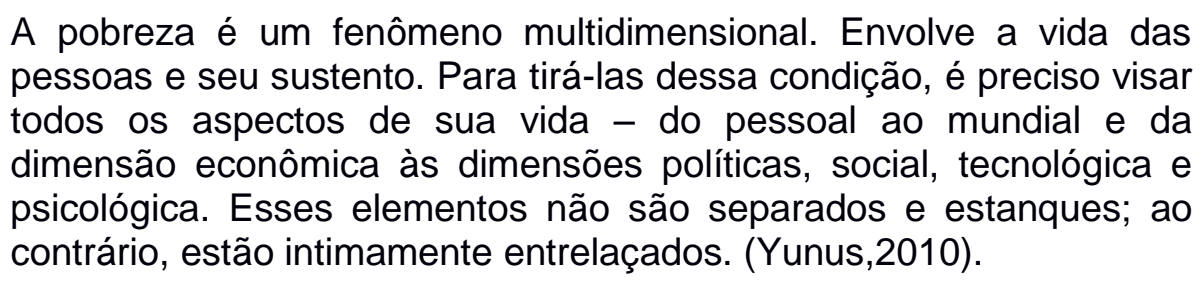

Exemplo de ações de políticas de microcrédito podem ser ilustradas pelas 25 organizações descritas como “ a família de empresas Grameen”,

A seguir:

Tabela 1

\begin{tabular}{|l|l|l|}
\hline Empesa & Fundação & Propósito \\
\hline
\end{tabular}




\begin{tabular}{|c|c|c|}
\hline Banco Gremeen & 1983 & $\begin{array}{l}\text { Serviços financeiros para os } \\
\text { pobres }\end{array}$ \\
\hline Grameen Trust & 1989 & $\begin{array}{l}\text { Treinamento, assistência técnica } \\
\text { e apoio financeiro às IMFs em } \\
\text { todo o mundo }\end{array}$ \\
\hline $\begin{array}{l}\text { Fundação Krishi (Agrícola) } \\
\text { Grameen }\end{array}$ & 1991 & $\begin{array}{l}\text { Experimentação e treinamento } \\
\text { para o aprimoramento da prática } \\
\text { e da produção agrícola. }\end{array}$ \\
\hline $\begin{array}{l}\text { Grameen Uddog } \\
\text { (Empreendimentos Grameen) }\end{array}$ & 1994 & $\begin{array}{l}\text { Exportação de tecidos feitos à } \\
\text { mão da marca Grameen Check. }\end{array}$ \\
\hline Fundo Grameen & 1994 & $\begin{array}{lrrr}\text { Capital de } & \text { risco } & \text { para } & 0 \\
\text { financiamento } & \text { de } & \text { novas } \\
\text { empresas } & \text { (iniciativas } & \text { de } \\
\text { empreendedorismo social) } & \end{array}$ \\
\hline $\begin{array}{l}\text { Fundação Grameen Mostho } \\
\text { O Pashusampad (Peixe e } \\
\text { Galo) }\end{array}$ & 1994 & $\begin{array}{l}\text { Viveiro de peixes e programa de } \\
\text { criação de gado. }\end{array}$ \\
\hline Telecomunicações Gameen & 1995 & $\begin{array}{l}\text { Serviços de telecomunicações } \\
\text { para os pobres. }\end{array}$ \\
\hline $\begin{array}{l}\text { Grameen Shamogree } \\
\text { (Produtos Grameen) }\end{array}$ & 1996 & $\begin{array}{l}\text { Venda de tecidos da Grameen } \\
\text { Check, feitos à mão, além de } \\
\text { artigos e produtos artesanais. }\end{array}$ \\
\hline
\end{tabular}




\begin{tabular}{|c|c|c|}
\hline Grameen Cybernet & 1996 & Provedor de serviços de internet. \\
\hline $\begin{array}{l}\text { Graemeen } \quad \text { Shakti } \\
\text { (Companhia } \quad \text { Energética } \\
\text { Grameen) }\end{array}$ & 1996 & $\begin{array}{l}\text { Fontes de energia renováveis } \\
\text { para áreas rurais de Bangladesh. }\end{array}$ \\
\hline Telefonia Grameen & 1996 & Serviços de telefonia celular. \\
\hline $\begin{array}{l}\text { Grameen Kalya (Previdência } \\
\text { Grameen) }\end{array}$ & 1996 & $\begin{array}{l}\text { Serviços de saúde e de } \\
\text { previdência para os membros e } \\
\text { equipe do Banco Grameen }\end{array}$ \\
\hline $\begin{array}{l}\text { Grameen Shikkha (Educação } \\
\text { Grameen }\end{array}$ & 1997 & $\begin{array}{l}\text { Bolsas de estudos e outros tipos } \\
\text { de assistência educacional aos } \\
\text { estudantes das famílias pobres. }\end{array}$ \\
\hline Comunicações Grameen & 1997 & $\begin{array}{l}\text { Provedor de serviços de internet } \\
\text { e serviços de processamento de } \\
\text { dados. }\end{array}$ \\
\hline Malharia Grameen & 1997 & $\begin{array}{l}\text { Fabricação de artigos de malha } \\
\text { para exportação. }\end{array}$ \\
\hline $\begin{array}{l}\text { Gerenciamento de Capital } \\
\text { Grameen }\end{array}$ & 1998 & Administração de investimento. \\
\hline Soluções Grameen & 1999 & $\begin{array}{l}\text { Desenvolvimento de soluções de } \\
\text { TI para empresas. }\end{array}$ \\
\hline
\end{tabular}




\begin{tabular}{|c|c|c|}
\hline $\begin{array}{ll}\text { Parque } & \text { Tecnológico } \\
\text { Grameen } & \end{array}$ & 2001 & $\begin{array}{l}\text { Desenvolvimento de instalações } \\
\text { de escritório de alta tecnologia } \\
\text { em Deca. }\end{array}$ \\
\hline $\begin{array}{l}\text { Grameen Byabosa Baikash } \\
\text { (Promoção de Negócios } \\
\text { Grameen }\end{array}$ & 2001 & $\begin{array}{l}\text { Provisão de garantias de } \\
\text { empréstimos para pequenas } \\
\text { empresas. }\end{array}$ \\
\hline Inforvia Grimeen & 2001 & $\begin{array}{l}\text { Conectividade de dados e } \\
\text { provedor de acesso à internet. }\end{array}$ \\
\hline Educação Grameen Star & 2002 & $\begin{array}{l}\text { Treinamento em tecnologia da } \\
\text { informação. }\end{array}$ \\
\hline Grameen Bitek & 2002 & $\begin{array}{lll}\text { Fabricação } & \text { e } & \text { produtos } \\
\text { eletrônicos. } & & \end{array}$ \\
\hline $\begin{array}{l}\text { Fundo de Assistência Médica } \\
\text { Grameen }\end{array}$ & 2006 & $\begin{array}{l}\text { Financiamento para os Serviços } \\
\text { de Assistência Médica Grameen. }\end{array}$ \\
\hline $\begin{array}{l}\text { Serviços de Assistência } \\
\text { Médica Grameen }\end{array}$ & 2006 & $\begin{array}{l}\text { Serviços de assistência medica } \\
\text { para os pobres. }\end{array}$ \\
\hline Grameen Danone & 2006 & $\begin{array}{l}\text { Alimentos nutritivos a preços } \\
\text { acessíveis para os pobres. }\end{array}$ \\
\hline
\end{tabular}

Adaptado do livro (Um mundo sem pobreza, p 91 e 92), 
Ou seja, realmente as políticas de microcrédito por si não retiram as pessoas da pobreza, entretanto somadas as ações de melhoria de vida disponibilizadas pela educação, saúde, assim como, pelos meios tecnológicos entre outros, podem promover um bem-estar social em vários setores da economia melhorando a condição de vida de muitas famílias pobres.

É importante ressalta, que conforme dados estatísticos do Banco Mundial e pelo Banco de Desenvolvimento da Ásia, apesar de Bangladesh apresentar tendências econômicas e sociais caminhando na direção certa, o país ainda é considerado um dos mais pobres do mundo, com dezenas de milhares de pessoas vivendo em nível pouco acima da subsistência. Isso reforça a informação de que as políticas de microcrédito e mais uma ferramenta que trabalha para a diminuição da pobreza e geração de renda.

Mesmo assim, as políticas propostas em Bangladesh assim como os desafios e as oportunidades oferecidas no país servem como exemplos importantes que podem ser compartilhados principalmente por países que estão em desenvolvimento como o Brasil.

Abaixo seguem algumas ações propostas em Bangladesh que podem ser aproveitadas por esses países, tais como:

- a necessidade de pensar estrategicamente na questão do desenvolvimento, analisando papel potencial de um país em sua região e no mundo a fim de buscar oportunidade de crescimento;

- a necessidade de superar mitos, estereótipos e pressupostos sobre os países pobres e suas relações com os vizinhos;

- a necessidade de encontrar abordagens diferentes e positivas para o seu povo, e não somente os problemas; e

- a necessidade de pensar como as empresas sociais podem cuidar dos problemas sociais e econômicos que normalmente são deixados para ser resolvidos pelo governo. 
A literatura nos revela que a pobreza no mundo é diferente em cada país e isso pode ser explicado e compreendido também, pelos fatores das variações econômicas existente em cada país assim como as condições culturais e até climática, por exemplo podem influenciar o nível de pobreza de uma região ou país, porém tudo isso não pode ser um fator de exclusão social dessas populações, por isso são necessárias a novas oportunidades de inclusão dessas pessoas.

Não se pode simplesmente alegar que em alguns países a pobreza é maior por conta das questões climáticas, por exemplo, visto que muitos países são devastados por tsunamis e logo em seguida consegue se reerguer sem causar muitos danos aquela população sem deixar indicadores de pobreza naquela região afetada.

Nesse sentido, seria possível saber quais indicadores podem identificar se uma população ou família saiu da pobreza?

Em Bangladesh, por exemplo, o Banco Grameen desenvolveu um sistema de pontos para realizar a medição por meio de um sistema de pontuação que descreve condições de vida específicas por meio de pontuação. Assim quando a família atinge dez pontos é sinalizado que aquela família saiu da pobreza.

Entretanto, quando os dez pontos não são atingidos, isso significa que aquela família ainda não conseguiu. Entretanto, por meio das condições especificas descritas é possível identificar o que está faltando para que essa família consiga sair da pobreza.

Somente para exemplificação uma das descrições dos questionários seria: " o membro do Banco Grameen e sua família bebem água pura encanada, água fervida ou água sem arsênico, purificada pelo uso de alume, tabletes de purificação ou filtros. "Se a resposta for positiva, indicando que todos essas ações ocorrem naquela família, então eles possuem um ponto dos dez.

Assim, como desenvolvido em Bangladesh, todos os países podem mensurar outros indicadores que sejam capazes de medir o nível de pobreza e os fatores que corrobora para que ela ocorra naquela família. 
Apesar de não ser especificamente o tema de estudo analisar as políticas de microcrédito da Bolívia, irei explanar apenas algumas ações desenvolvidas lá, somente para exemplificar que 0 microcrédito pode atuar e ser eficiente independentemente das condições enfrentadas pelo país seja no campo da economia ou da política.

Uma experiência com objetivos bem parecidos com a da Índia foi realizada na Bolívia com o auxílio de organizações internacionais.

Assim em 1986, muito depois das experiências realizadas em Bangladesh, com o auxílio da ACCION, que é uma agência privada norte-americana que tem como objetivo treinar e prestar assessoria técnica a instituições de microfinanças auxiliando-as no processo de tornarem-se autossustentável.

Deste modo com o auxílio dos recursos disponibilizados pela Fundação Calmeadow e da USAID, que são agências de fomento, a primeira canadense e a segunda norte-americana, foram lançadas na Bolívia o PRODEM, que contava com a participação dos empresários e do governo boliviano com o objetivo de disponibilizar empréstimos direcionados para os microempresários do país.

Assim com essa iniciativa, existem relatos que até o ano de 1991 esse projeto foi um sucesso, entretanto o programa depois de 1991 passou por grandes problemas relacionados a constituição jurídica, tendo em vista que para efetuarem a captação de recursos que se dava em função de uma organização nãogovernamental por conta disso existia a limitação de recursos a serem adquiridos.

Por conseguinte, decidiram em 1992 transformar-se em um banco comercial do mundo especializado em microfinanças: conhecido popularmente na Bolívia como Banco Sol ou Solidário.

Essa medida proporcionou ao país um grande avanço, tendo em vista que com essa ação a instituição se tornou autossuficiente. E com essas iniciativas a Bolívia que é considerada um dos países mais pobres da América do Sul, transformou-se em referência nas políticas de microfinanças. 
Ou seja, quando várias instituições juntamente com a população e seus governos se mobilizam para realizar ações de desenvolvimento para o país, percebe-se que pode ser possível.

Por fim, é perceptível que assim como na Índia e na Bolívia, ações como essa promovida nesses dois países podem gerar um impacto positivo na vida de milhares de famílias. Nesse sentido, fica a seguinte pergunta, devemos esperar ações dos governos para promover mudanças como essas realizadas em Bangladesh ou na Bolívia? Ou seja, a sociedade como um todo envolvendo todos os fatores preponderantes da economia poderia promover a extinção da pobreza, deixando a cargo dos governos somente a parte da legislação como forma de guiar os trabalhos?

\subsection{Política de Microcrédito no Brasil}

A política de microcrédito no Brasil é conhecida como a concessão de empréstimos a micro e pequenos empreendedores que necessitam de crédito, mas que não possuem acesso a ele de forma tradicional (BANCO CENTRAL-BACEN).

A história da política de microcrédito no Brasil teve início por volta de 1973, com a criação da União Nordestina de Assistência a Pequenas Organizações, conhecida popularmente como Programa UNO que atuou no Brasil durante 18 anos.

Autores como Dantas (2014) falam que a UNO, era atuante nas capitais Recife e Salvador, seu público informal era composto principalmente por economia urbana e sua metodologia era dar capacitação aos pequenos empreendedores viabilizando de alguma maneira esses pequenos empreendedores por meio do microcrédito desenvolvessem alguma atividade por conta própria.

Essa instituição juridicamente era uma associação civil, sem fins lucrativos e contava com a parceria de várias entidades internacionais como a Accion International, por exemplo, mundialmente conhecida como AITEC. 
Com relação a esse programa se fizermos um paralelo entre as políticas de microcrédito da UNO com as políticas de microcrédito de Bangladesh, podemos perceber que os técnicos da UNO, prestavam orientações de maneira a indicar a melhor forma segundo eles deveriam ser aplicados os recursos. Por outro lado, em Bangladesh eles incentivam os pequenos empreendedores a decidirem sozinhos como aplicarão e usarão os recursos emprestados, "lá os funcionários do Banco Grameen são treinados a não fornecer ideias de como deverá ser aplicado o dinheiro " fazendo com que aquele artesão utilizasse de sua criatividade e escolha a melhor maneira de como aplicar o dinheiro.

O programa UNO era formado por organizações não governamental que são especializadas em microcrédito e capacitação para trabalhadores de baixa renda do setor informal.

De acordo com Dantas (2014), a UNO tinha como objetivos: a) demonstrar para as autoridades que se um empreendedor pobre, informal recebesse um crédito para investir em sua atividade econômica o pagaria adequadamente; b) que esse crédito, ao longo de certo período, fortaleceria essa atividade, melhoraria as condições de vida da família e criaria novos postos de trabalho.

Destarte, esse programa inicialmente dava capacitação sobre gerenciamento aos seus clientes, assim como efetuava pesquisas sobre o perfil do microempresário informal e o impacto do crédito. Entretanto, se comparado a Índia onde se criava pequenos grupos de artesãos, aqui esse trabalho resultou na formação de uma associação, com a criação de cooperativas, associações de artesãos e de grupos de compras.

Com essa iniciativa a UNO financiou milhares de pequenos empreendedores, assim como, financiou diferentes estados brasileiros a formarem profissionais especialistas em crédito no setor informal. Durante muitos anos esse programa serviu como referência para a expansão dos programas de microcrédito da América Latina.

A UNO empenhou-se com essas ações por mais de dezoito anos, e apesar do seu enorme sucesso tanto técnico quanto metodológico no ano de 1991 ela 
fechou as portas, e não cabe esclarecer aqui os motivos pelos quais isso correu, porém, alguns estudos mostram que a falta de sustentabilidade financeira de longo prazo tenha colaborado para o encerramento de suas atividades.

Entretanto, cabe ressaltar que durante a sua atuação ela colaborou com projetos pilotos e que na atuação do microcrédito serviu como referência na América Latina.

Ao falarmos no processo de microcrédito do Brasil é importante ressalta que ele foi e é influenciado por vários fatores econômicos e culturais. Também não podemos esquecer que a própria legislação vigente, quando comparado ao microcrédito realizado em outros países, ainda é uma política pouco difundida com relação ao seu funcionamento efetivamente e para o que ele realmente serve.

Assim, ainda é um serviço que tem um grande potencial de crescimento. Tendo em vista que alguns programas de microcrédito ofertam somente o crédito, quando poderiam aliar a outros serviços.

Uma pesquisa realizada em 2000 pelo Instituto Brasileiro de Administração Municipal (IBAM) sobre as microfinanças no Brasil traçou um perfil das instituições que já atuam no país. A pesquisa revelou que $38,1 \%$ das instituições de microcrédito analisadas ofertam somente o crédito. A maioria oferta um outro produto ou serviço, como capacitação ou assessoria, ou ainda os dois juntos.

Nesse sentido percebe-se o quando o microcrédito ainda pode colaborar com a oferta de outros serviços que possam gerar emprego e renda.

Atualmente, no âmbito nacional existem três segmentos de políticas de microcrédito efetivamente como programas, eles abrangem vários setores de suma importância na economia brasileira entre eles podemos citar Sociedade Civil, Iniciativa Privada e Setor Público.

Nesse sentido, iremos comentar um pouco sobre cada setor que de certa forma possam promover melhorias por meios de parcerias para a disponibilização de vários serviços que contribuiriam com as pessoas de baixa renda no sentido dessas parcerias gerarem aumento de renda e consequentemente melhorando o acesso em 
outros segmentos como saúde, educação e infraestrutura, sobretudo fiscalizando para que as ações desenvolvidas por essas parcerias possam atingir pessoas que realmente precisam se beneficiar com essas políticas. Como já ocorrem em outros países.

Por conseguinte, voltando aos setores da economia brasileira, começaremos a falar obre a sociedade civil atuante em vários segmentos da economia destacando uma de suas políticas desenvolvidas pelo Banco da Mulher.

O Banco da Mulher é uma instituição sem fins lucrativos qualificada como Organização da Sociedade Civil de Interesse Público-OSCIP, e é uma ação voltada a população de baixa renda, esse banco foi constituído em 1989 com o apoio do Fundo das Nações Unidas para a Infância/UNICEF e do Banco Interamericano de Desenvolvimento-BID, apesar de o banco da mulher inicialmente atender somente mulheres, posteriormente expandiu para o público masculino. Atualmente esse banco atua em vários estados brasileiros.

A iniciativa Privada por sua vez, desenvolve um papel muito importante nas políticas de microcrédito como parceiras no setor público, porém as ações desenvolvidas pelo setor privado ainda possuem um papel muito pequeno no desenvolvimento do microcrédito diante do tamanho do seu potencial. Entretanto, as poucas ações que existem são no sentido de reagir as implementadas pelo setor público, mas mesmo sendo poucas essas ações conseguem ser eficientes e são fundamentais para o fortalecimento da política de microcrédito.

Assim, percebe-se que a parceria é necessária, tendo em vista que não existe setor privado forte se não existir um setor público eficiente e competitivo, então o próprio setor privado percebe que é questão de sobrevivência ter essa eficiência e efetividade do setor público.

Por conseguinte, percebe-se que estas também são propostas ações e implementações de política de microcrédito todas com o intuito da diminuição da pobreza e também de inclusão social. Pois, o acesso ao crédito para aqueles menos favorecidos na economia pode ser uma das alternativas favoráveis para a redução das desigualdades sociais e econômicas existentes em nosso país. 
Entretanto, assim como em outros países é necessário que sejam quebradas as barreiras, sobretudo institucionais de maneira que a inclusão dos mais necessitados ocorra de maneira eficiente no sistema financeiro de crédito.

Partindo desse ponto, é claramente perceptível o grande potencial demandado por pessoas de baixa renda que necessitam do acesso às operações de microcrédito, seja para sair dar extrema pobreza ou até mesmo em busca de outras demandas disponibilizadas pelo acesso ao crédito.

O que é bem falado na literatura e que precisa ser compreendido pela sociedade como um todo é que as políticas de microcrédito produzem não só o desenvolvimento das pessoas como também é um fato gerador de renda, e que também traz muitos benefícios para o país em especial promovem o desenvolvimento da localidade onde a política foi implementada.

Assim, quanto mais políticas de microcrédito forem implementadas menor será a disparidade econômica entre seus cidadãos e maior será a inclusão aos sistemas financeiro de crédito tradicional, pois com o aumento da renda as pessoas mais pobres que antes eram imperceptíveis para o sistema financeiro tradicional apresentado pelos bancos, passam a ser peças fundamentais para o desenvolvimento econômico e social.

No brasil, embora existam vários atores a favor do microcrédito como uma política de inclusão social, essa iniciativa ainda é vista de forma marginalizada e muitas vezes colocada como se fosse uma obrigação exclusiva do governo.

Realmente o governo pode proporcionar muitos programas nesse sentido, pois existem algumas funções sociais de interesse da sociedade como um todo que não podem ser prestadas por entidades privadas, como as desempenhadas pelo Banco Central, por exemplo, que cuida das atividades bancarias as quais jamais poderia ser prestada pelas entidades privadas. Assim como a segurança pública, que também não poderia ser prestada pela iniciativa privada.

No entanto, nem mesmo todas as ações desenvolvidas pelo governo serão suficientes para erradicar os problemas sociais existentes em nosso país e a própria literatura não traz relatos de países que conseguiram sozinhos. Porém é importante 
ressalta que o governo de maneira geral poderá sim influenciar a maneira como serão realizadas essas ações incentivando as entidades privadas a caminharem juntamente com os governos a encontrar soluções no intuito de resolver questões em áreas que são negligenciadas.

Não se pode exigir ou esperar que as entidades privadas se tornem sozinhas executoras dessas políticas, muito menos que elas solucionem essas questões, assim como os governos também não obterão êxito sozinhos.

Entretanto, no tratamento de questões sociais é evidente que o governo consegue se mobilizar com muitos recursos em prol dessas ações utilizando-se de vários meios tais como por meio do recolhimento dos impostos, por empréstimos realizados a outros países. Contudo, é sabido que essas iniciativas por si só não trazem todos os recursos necessários nem a eficiência capaz de resolver essas questões.

Assim, é necessário que o governo trabalhe com mais parcerias com entidades privadas, pois sabemos que sozinho o governo apesar de consegui mobilizar recursos, estes podem ser ineficientes e burocratizados inviabilizado de certa forma que essas ações acontecem na rapidez que os mais pobres precisam que elas ocorram.

Apesar de existirem em nosso país alguns estudos sobre o microcrédito, ainda faltam estudos comparativos e confiáveis de controle voltados para medir a eficiência das políticas de microcrédito, visto que as existentes não tratam especialmente sobre eficiência, assim como também não existem trabalhos empíricos satisfatórias para avaliar os impactos dessas políticas de microcrédito.

Talvez com a realização de estudos voltados especificamente para esse tema mostrando o impacto e a eficiência que essa política pode proporciona aos mais necessitados possam de certa forma sensibilizar os governos e as entidades privadas como um todo.

Por fim, é de conhecimento da população brasileira as carências que ainda assolam no nosso país, ainda existem muitas necessidades que deverão ser supridas, não se pode deixar que aqueles que mais precisam sejam na maioria das 
vezes esquecidos pelos governantes ou pela sociedade. É dever do estado e da sociedade garantir que todos se tornem verdadeiros cidadãos.

\subsection{Política de Microcrocrédito do Governo Federal}

Sabe-se que historicamente o Brasil é marcado por uma extraordinária desigualdade social e econômica. Assim as mudanças econômicas e sociais ocorridas no governo Lula, sobretudo com relação à redução da pobreza e a redistribuição da renda ocorrida, nesse período do governo, são vistas por especialista como ações inovadoras e caracterizam uma inovação na parte social e econômica das pessoas de baixa renda.

Em meados dos anos 2000, o Brasil foi caracterizado pela criação de várias Instituições de Microfinanças - IMFs, que se organizavam como organizações da sociedade civil e trabalhavam com parcerias em alguns casos com os entes governamentais.

Assim, logo no início do governo Lula, já se percebia uma preocupação do governo com a exclusão da população de baixa renda ao mercado de crédito. Logo no ano de 2003 foi criada a resolução de número 286 do Conselho Deliberativo do Fundo de Amparo ao Trabalhador - CODEFAT, do Ministério do Trabalho. Essa resolução autorizava que fossem alocados $R \$ 1,0$ bilhão nas IMFs, especificamente para as operações de microcrédito. (COSTA, 2010).

No mesmo ano o Banco Central criou a Resolução № 3109, regulamentada na Lei. 10.735 de setembro de 2003, que instituiu o direcionamento de $2 \%$ dos depósitos à vista de diversas entidades financeiras para operações de microfinanças. Todas essas ações ilustram a preocupação do governo nas políticas de microfinanças. Tendo em vista a escassa disponibilidade de recursos para as operações de crédito para a população de baixa renda.

No seu primeiro pronunciamento, Lula afirmou que "a vitória significa a escolha de um projeto alternativo e o início de um novo ciclo histórico para o Brasil”. Lula foi categórico: "a maioria da sociedade brasileira votou pela adoção de outro modelo econômico e social, capaz de assegurar a retomada do crescimento, do 
desenvolvimento econômico com geração de emprego e distribuição de renda" (GONÇALVES, 2003).

No livro 10 anos de governos pós-neoliberais Lula e Dilma (JORGE MATTOSO, p.111):

Desde o início desse período em 2003, quando da posse do primeiro governo de Lula, o país buscou sair de um imbróglio no qual se encontrava havia duas décadas, marcado por um crescimento econômico insuficiente, baixas taxas de investimento, acentuada vulnerabilidade externa, redução da capacidade de intervenção e regulação do Estado, elevação do desemprego, precarização do trabalho e aprofundamento de nossas vergonhosas miséria e desigualdade.

Ainda segundo o autor, o sucesso dos governos eleitos após 2002 não se deveu exclusivamente à esfera da economia ou do social, mas ao uso de políticas inovadoras capazes de articular o econômico e o social e potencializar o crescimento, a produtividade e a institucionalidade, gerando algo inexistente ao longo das duas décadas anteriores, o desenvolvimento.

Por outro lado, de acordo com A Pesquisa Nacional por Amostra de Domicílios -PNAD, a desigualdade de renda no Brasil vem caindo continuamente desde 2001. Entre 2001 e 2011, a renda per capita dos 10\% mais ricos aumentou $16,6 \%$ em termos acumulados, enquanto a renda dos mais pobres cresceu notáveis $91,2 \%$ no período. Ou seja, a do décimo mais pobres cresceu $550 \%$ mais rápido que a dos $10 \%$ mais ricos. Os ganhos de renda obtidos aumentam paulatinamente, na medida em que caminhamos do topo para a base da distribuição de renda. (INSTITUTO DE PESQUISA ECONÔMICA APLICADA- IPEIA, 2012).

Nesse sentido, percebe-se os avanços econômicos e sociais do governo federal entre os períodos de 2001 e 2011. Entretanto, o objetivo aqui não é falar sobre todas as políticas implementadas pelo ex-presidente, mas sobretudo falar sobre as políticas de inclusão social por meio do microcrédito.

Assim, iniciaremos falando um pouco sobre a legislação especificadamente sobre o Plano Nacional de Microcrédito Produtivo Orientado-PNMPO. 
Desde meados da década de 90, o governo brasileiro já vinha se manifestando no intuito de propor a criação de condições necessárias para que as pessoas de baixa renda tivessem acesso a serviços e produtos financeiros, e isso foi possível culminando na criação do Programa Nacional de Microcrédito Produtivo Orientado (PNMPO), instituído em 2005 no governo do ex-presidente Lula.

Até então a legislação não tratava das questões de microcrédito orientado amparado por lei, assim em 25 de abril de 2005, a Lei Federal no 11.110 instituiu, no âmbito do Ministério do Trabalho e Emprego, o Programa Nacional de Microcrédito Produtivo Orientado - PNMP.

Esse programa apresenta várias ações de política de microcrédito. Assim será citado alguns dos seus principais objetivos segundo a Lei:

a) ampliar o acesso ao crédito entre a população de baixa renda e, com isso, incentivar a geração de trabalho e renda entre os microempreendedores populares formais e informais;

b) disponibilizar recursos para o microcrédito produtivo orientado;

c) integrar o microcrédito com as demais políticas de desenvolvimento implementadas pelo Estado e pela sociedade civil;

d) fortalecer e ampliar uma rede autônoma e perene de financiamento da economia popular;

e) intermediar a interlocução entre os operadores do setor e oferecer apoio técnico às instituições de microcrédito produtivo orientado para o seu fortalecimento institucional.

Esse programa conforme o seu paragrafo terceiro é voltado tanto para pessoas físicas como para pessoas jurídicas que desenvolvam atividades produtivas de pequeno porte.

A Resolução no. 3.422/2006, do Conselho Monetário Nacional, possui a finalidade específica de disponibilizar recursos para o microcrédito produtivo orientado, conforme definido pela Lei Federal nำ11.110/2005 em seu artigo $1^{\circ}$, no §3ํ, estabelece que: 
Art. 1 - Fica instituído, no âmbito do Ministério do Trabalho e Emprego, o Programa Nacional de Microcrédito Produtivo Orientado - PNMPO, com o objetivo de incentivar a geração de trabalho e renda entre os microempreendedores populares.

§ 30 Para os efeitos desta Lei, considera-se microcrédito produtivo orientado o crédito concedido para o atendimento das necessidades financeiras de pessoas físicas e jurídicas empreendedoras de atividades produtivas de pequeno porte, utilizando metodologia baseada no relacionamento direto com os empreendedores no local onde é executada a atividade econômica, devendo ser considerado, ainda, que:

I - o atendimento ao tomador final dos recursos deve ser feito por pessoas treinadas para efetuar o levantamento socioeconômico e prestar orientação educativa sobre o planejamento do negócio, para definição das necessidades de crédito e de gestão voltadas para $o$ desenvolvimento do empreendimento;

II - o contato com o tomador final dos recursos deve ser mantido durante o período do contrato, para acompanhamento e orientação, visando ao seu melhor aproveitamento e aplicação, bem como ao crescimento e sustentabilidade da atividade econômica; e

III - o valor e as condições do crédito devem ser definidos após a avaliação da atividade e da capacidade de endividamento do tomador final dos recursos, em estreita interlocução com este e em consonância com o previsto nesta Lei.

Nesse sentido, segundo a Lei o que caracteriza, portanto, o microcrédito orientado à produção, além do porte do tomador do empréstimo, é a metodologia utilizada durante todo o período contratado. 
Por conseguinte, a Resolução no 3.422 , de 30 de novembro de 2006, do Conselho Monetário Nacional, regulamentou que a realização de operações de microcrédito destinadas à população de baixa renda e a microempreendedores seriam realizadas com os recursos provenientes da parcela de depósitos à vista captados por instituições financeiras.

Desse modo, os recursos que compõem essa carteira são provenientes da imposição legal de aplicação obrigatória em investimentos em operações de microcrédito de parte dos depósitos captados à vista por instituições financeiras.

A Lei № 11.110, que criou o Plano Nacional de Microcrédito Produtivo Orientado (PNMPO), no Brasil, permitiu que os bancos comerciais pudessem destinar até $2 \%$ dos depósitos mantidos em reservas no Banco Central à atividade de microcrédito, diretamente, ou via financiamento de carteiras de instituições de microcrédito.

Com a criação da lei percebe-se que foram criadas várias benesses, sobretudo para as pessoas de baixa renda.

Autores como Santos, dizem que o PNMPO, ao criar formas alternativas de financiamento para as IMFs e "um marco regulatório próprio" foi marcante na trajetória das microfinanças no Brasil (2014, p. 127).

Ainda segundo o mesmo autor, o PNMPO ilustrou bem a estratégia governamental quanto a políticas de microcrédito, que se baseia em três pilares "a capilaridade dos bancos federais, os recursos públicos para financiar operações e os subsídio da taxa de juros" para fortalecer todo o setor de microcrédito brasileiro.

Assim como existem vários elogios com relação a criação da lei, existem também algumas críticas, sobretudo com relação as políticas aplicadas pelos bancos.

Segundo a Folha de São Paulo, nem mesmo os bancos públicos cumpriram as exigências de destina $2 \%$ do dinheiro captado nas contas correntes ao microcrédito. 
Destarte, todas as operações são fiscalizadas pelo Banco Central do Brasil (BCB), que é o órgão responsável por cumprir e fiscalizar, no País, as disposições e normas expedidas pelo Conselho Monetário Nacional (CMN) que regula 0 funcionamento do Sistema Financeiro Nacional (SFN).

Alguns autores, ao analisarem os últimos dez anos de política econômica do governo, apontam que foram marcados pela criação de um novo modelo de desenvolvimento da economia brasileira, baseado na expansão do mercado interno e com uma forte atuação do Estado para reduzir a desigualdade na distribuição de renda.

Jardim (2009), considera que as ações do governo Lula apresentam uma peculiaridade justamente por ser um partido historicamente de esquerda, que tem priorizado projetos de inclusão social, como o microcrédito.

Aqui é importante ressaltar que as políticas de microcréditos implementadas no governo Lula seriam uma continuação das políticas do governo anterior Fernando Henrique Cardoso. Lula então teria dado à política um caráter mais social que $\mathrm{FHC} e$ de modo que nenhum outro presidente da República brasileira tinha conseguido em toda história.

Com relação a liberalização e acesso ao crédito com a chegada de um novo governo, existia de certa forma uma grande especulação com relação ao acesso ao crédito, sobretudo das pessoas mais pobres. Com a publicação da Lei 10.735 de 2003, que tratava justamente do direcionamento de depósitos à vista captados pelas instituições financeira par operações de crédito destinadas à população de baixa renda e a microempreendedores, foi de certa maneira tranquilizador a inserção de uma lei que proporcionava a inclusão social dessas pessoas.

Alguns autores, costumam classificar essa promoção de inclusão social que atingem as pessoas de baixa renda a esse processo de inclusão que ficou popularmente conhecido como a " bancarização dos pobres" visto que até a criação da lei muito quase ninguém de baixa renda de acesso aos serviços bancários. 
Nesse sentido, podemos afirmar que a eleição de um Presidente da República de um partido de esquerda conduziu, então um novo modelo de política econômica.

Tudo isso pode ser reforçado com a criação de programas de transferência de renda em seu primeiro mandato por meio do programa Bolsa Família, promovendo acessibilidade e poder de compra das famílias de baixa renda.

Por meio dessas políticas podemos perceber que foram desenvolvidos vários projetos de acessibilidade das classes populares, a terem mais acesso a algumas linhas de crédito existentes no mercado financeiro. Assim como foi promovido uma maior aproximação entre o sistema financeiro e o governo que se lançou dessa oportunidade e realizou várias parcerias no mercado.

No entanto, alguns autores criticam o fornecimento de créditos a pessoas de baixa renda, com a alegação de que isso poderia provocar um maior endividamento e uma certa dependência financeira mesmos sendo ofertados juros diferenciados do atual sistema de crédito fornecido à classe média.

No sentido de explicar melhor a trajetória das ações de políticas de microcrédito do governo do Partido dos trabalhadores - PT, será citada uma pesquisa de campo realizada de 16 a 19 de março de 2012, pela CNI-IBOPE Retratos da Sociedade Brasileira: Inclusão Financeira, essa pesquisa foi feita com 2002 entrevistados em 141 municípios. Ela fala sobre a inclusão financeira do Brasil iniciado no ano de 2000. Na pesquisa observou-se que $36 \%$ dos brasileiros não tinha conta em banco, e esse percentual era ainda maior para os estratos inferiores de renda e escolaridade. As pessoas que tinham renda familiar até um salário mínimo, para fins de exemplo, 64\% não possuíam conta em bancos.

Assim, (90\%) dessas pessoas que não tinha acesso ao sistema financeiro tradicional e que por sua vez precisavam pagar suas contas utilizavam os correspondentes bancários, (60\%). Alegavam que não tinha conta em bancos por não possuir condições financeiras. Entretanto, é a população de baixa renda a que reporta a maior dificuldade em quitar suas dívidas (48\% consideram difícil ou muito 
difícil pagá-las) e também a que mais se endivida através de carnês ou cadernetas de lojas (32\% das dívidas). (CONFEDERAÇÃO NACIONAL DA INDÚSTRIA, 2012)

É evidente que os resultados alcançados nesta pesquisa demonstram o quão desigual é o nosso país, sobretudo para os mais pobres que sofrem com tantas mazelas, é desigual não somente com relação a renda, mais também com relação a sua escolaridade e acessibilidade aos serviços ofertados.

Somente para efeito de comparação em Bangladesh os analfabetos não podem ser titulares de contas em banco. Assim como é demonstrada na pesquisa: as pessoas que são pobres e que são menos escolarizadas, ainda são excluídas do sistema financeiro tradicional.

Malgrado, a alternativa disponibilizada para eles, por sua vez são os correspondentes bancários, como os correios, loterias da caixa e correspondentes Bradesco, por exemplo, essas empresas atuam como intermediários entre instituições financeiras e seus clientes, representam uma importante dimensão do Sistema Financeiro Nacional (SFN).

Para finaliza, cabe ressaltar que mesmo com os avanços nas diversas políticas com relação ao acesso ao crédito, na gestão do governo Lula, é possível perceber que ainda existe uma baixa penetração das IMFs no sistema financeiro.

De acordo com Monzoni (2006), o microcrédito possui grande potencial de crescimento na economia brasileira. Segundo relatado em sua tese, o microcrédito no Brasil tem uma taxa de penetração muito baixa e a oferta desse serviço encontrase muito aquém a sua demanda.

Dando continuidade às políticas do ex-presidente Lula em primeiro de janeiro de 2011 a presidente Dilma Russeff dá início ao seu primeiro mandato. Esse momento foi considerado histórico, tendo em vista que ela foi a primeira mulher e até o momento a única a ser presidente do Brasil. Nessa gestão foi dando segmento em sua grande maioria às políticas econômicas do governo anterior.

Estudos sobre o seu primeiro ano de governo, elaborado pelo Centro de Pesquisa e Apoio aos Trabalhadores, considerou que "os princípios que nortearam a 
sua atuação inicial derivaram de um modelo desenvolvimentista, em que o Estado tem importante papel na regulamentação e no fomento do crescimento econômico, bem como na definição das estratégias para o crescimento".

Durante o Governo Dilma, a questão do microcrédito foi incorporada ao âmbito do Plano Brasil Sem Miséria, mais especificamente em sua dimensão de inclusão produtiva, por meio do Programa Nacional de Microcrédito Crescer, implementado em agosto de 2011.O Crescer apoiou-se em todos os avanços, regulatórios e de financiamento, alcançados pelo PNMPO (SANTOS, 2014).

Assim, o Programa Nacional de Microcrédito Produtivo que já existia no governo Lula foi mantido, entretanto foi repaginado com foco nas operações voltadas aos pequenos negócios que ficou conhecido como Programa Crescer. Ele continua sendo um programa de microcrédito produtivo orientado para facilitar o acesso dos pequenos empreendedores aos recursos necessários para abrir, manter e expandir seus negócios.

E segundo o seu programa de campanha 2014, em menos de três anos, o CRESCER concedeu $\mathrm{R} \$ 14,1$ bilhões em crédito, em 9,4 milhões de operações. Deste total, um terço foi realizado por beneficiários do Bolsa Família, que buscam fortalecer seu pequeno negócio com o microcrédito.

Segundo pesquisas de opinião em seu primeiro mandato foram registrados elevados índices de popularidade do governo da presidenta, indicando um amplo reconhecimento pelos brasileiros dessa histórica transformação da realidade econômica e social do país iniciada em 2003 com o primeiro governo Lula, que desde então foi constantemente aprofundada com inovadoras políticas de desenvolvimento, combate à pobreza e distribuição da renda, mesmo durante crises externas.

Sabe-se que ocorreram em seu governo muitas mudanças na composição da sociedade brasileira, com as iniciativas de transferência de renda, com um olhar e com o objetivo de inclusão social e redução da pobreza, tudo isso promoveram um maior acesso ao crédito às pessoas de baixa renda, assim todas essas ações são 
importantes como passos iniciais rumo à erradicação da enorme pobreza existente em nosso país.

Assim, apesar das grandes mudanças serem percebidas com maior intensidade nos tempos atuais, uma ressalva, porém, deve ser feita. Esse processo de um estado mais atuante e regulador já vinha sendo implementado desde a década de 90.

Entretanto tanto no governo do ex-presidente Lula, assim como no atual governo de Dilma, os programas de microcrédito não decolaram plenamente conforme a necessidade da população de baixa renda.

Também é de conhecimento da sociedade que o programa social de maior visibilidade até então no país e que popularmente é considerado o carro chefe do governo do PT, é o Bolsa Família. O programa conseguiu modificar o panorama das políticas sociais nos anos 2000 e se consolidou como "política de Estado, e não de governo" (BICHIR, 2010).

Por outro lado, existem autores que criticam a maneira pelas quais essas políticas são conduzidas. "o 'quase tudo' da política social brasileira", Bolsa Família, ao se tornar consolidou, para o sistema de proteção social brasileiro, uma ruptura: de um sistema universalista, desenhado na Constituição de 1988, para um sistema incompleto e focalizado (LAVINAS, 2007).

Já para outros autores esses programas sociais foram acompanhados de melhorias na condição social das pessoas de baixa renda e, no campo da política social, por uma importante modificação no sistema de proteção social brasileiro: políticas focadas na transferência de renda, como o Bolsa Família, assumiram papel central.

Para finalizar, percebe-se que ao contrário de outros países, que no Brasil, o microcrédito foi apropriado como uma política pública, e conduzida primordialmente, por órgãos do próprio governo. Com a gestão do governo Lula, as políticas de microcrédito foram associadas diretamente às iniciativas relacionadas à Economia Solidária, assim como no governo Dilma, o microcrédito foi uma das peças chave da dimensão de inclusão produtiva com o Plano Brasil Sem Miséria. 


\subsection{Política de Microcrédito do Banco do Nordeste - BNB}

\subsection{CrediAmigo}

A história do Banco do Nordeste - BNB, deu início no governo de Getúlio Vargas. Em 1951 o Estado do Nordeste sofreu vários estragos em consequência da grande seca de 51, na época o então Ministro da Fazenda, era Horácio Lafer, após uma viagem ao nordeste, o ministro apresentou exposição de motivos ao Presidente Getúlio Vargas para a fundamentação da lei que criaria o Banco do Nordeste.

Assim em 19 de junho de1952, o Banco foi criado pela Lei Federal oㅜ 1.649, como uma instituição financeira múltipla e organizada sob a forma de sociedade de economia mista, de capital aberto, tendo mais de $90 \%$ de seu capital sob o controle do Governo Federal.

Desse modo percebe-se que o BNB é uma instituição financeira estatal constituída na forma de sociedade de economista mista de capital aberto, mas é controlada pelo governo federal, assim o Banco desenvolve várias ações que auxilia tanto na inclusão social quanto na econômica atuando nos nove estados da Região Nordeste, no Norte de Minhas Gerais e no Norte do Espirito Santo.

Segundo informações do site do Banco, seus ativos são em torno de 60 bilhões de reais e atua em 1990 municípios.

Assim iniciaremos agora a falar sobre o maior programa realizado pelo BNB, que funciona desde 1998 e é considerado o seu maior programa de microcrédito, o CrediAmigo.

Esse programa atua principalmente nas regiões do Nordeste, sobretudo no atendimento dos mais pobres cuja maioria dos beneficiários estão sem trabalhar no mercado formal e iniciam pequenas atividades por conta própria.

Assim, o CrediAmigo é uma linha de credito fornecida pelo BNB, e que tem como objetivo principal oferecer uma linha de crédito sem muita burocracia de maneira rápida a microempreendedores atendidos por ele. Dessa maneira, ele possui rapidez sem muita burocracia devido a metodologia do programa adotada por meio do aval solidário. 
Ou seja, várias pessoas que necessitam adquirir o crédito se reúnem e promovem um representante que atua em nome do grupo, sendo que todos respondem de maneira solidária junto ao banco. Funciona como uma espécie de avalista uns dos outros.

Segundo informações do site do Banco do Nordeste, os documentos necessários para o cadastro do CrediAmigo são:

- CPF, documento de identificação com foto e comprovante e residência atual;

- O atendimento ao cliente do CrediAmigo é personalizado, feito no próprio local do empreendimento;

- O empréstimo é liberado de uma só vez em no máximo sete dias úteis após a sua solicitação;

- Os valores iniciais variam de $R \$ 100,00$ a 6.000 , de acordo com o produto, a necessidade e o porte do negócio;e

- O empréstimo pode ser renovados e evoluir até $R \$ 15.000,00$, dependendo do produto, da capacidade de pagamento e da estrutura do negócio permanecendo esse valor como endividamento máximo do cliente.

Dessa maneira o programa vem sendo o principal programa de microcrédito no Brasil.

O CrediAmigo é o maior programa de microcrédito brasileiro e o maior da América Latina, ele funciona como Microcrédito Produtivo Orientado. Até dezembro de 2001 , tinha realizado 599,8 mil operações no valor de $R \$ 440$ milhões. Sua inclusão leva a um aumento de $110,23 \%$ no total de operações de microcrédito no Brasil. (BID, 2000)

Isso significa que o CrediAmigo é um programa autossustentável, e isso quer dizer que não depende de incentivos fiscais. 
Diversos estudos sobre o CrediAmigo, têm revelado os impactos dele como uma política capaz de gerar emprego e renda. Em cada estudo os autores revelam seu ponto de vista a respeito do programa, sobretudo em seu aspecto positivo.

Souza (2008) cita que "o Programa CrediAmigo demonstrou ser uma política de crédito transformadora que procura trazer soluções a partir da potencialidade do cliente e o desenvolvimento dos negócios por meio do acesso ao crédito" (Souza, 2008: 114).

Monzoni (2007) estaca que: "Não é possível abordar as microfinanças do Brasil sem falar do BNB. Mesmo não tendo sido um pioneiro no mercado, o Programa CrediAmigo do BNB representa hoje mais de $60 \%$ do mercado nacional de microcrédito produtivo orientado em clientes atendidos e $46,5 \%$ em carteira ativa. " (Monzoni, 2007: 66-67).

Para Otero (2000), o programa do BNB é uma das únicas iniciativas mundiais bem-sucedidas realizadas por bancos estatais, ao lado do Bank Rakyat Indonésia.

Outros estudos revelam ainda que o grande sucesso se dá, justamente pelo fato do tipo de garantia solicitada pelo banco que é o aval solidário ao invés de altas taxas de juros de mercado.

Ainda segundo o site do BNB, a garantia exigida para esse tipo de operações é realizada pelos grupos que tomou o crédito em conjunto, ou seja, o compromisso em pagar a dívida é de todos. E isso, diminui muito os riscos das operações ofertadas.

Nesse ponto com relação as garantias, percebe-se que é bem semelhante as garantias solicitadas pelo Banco Grameen em Bangladesh.

Segundo o site do Banco do Nordeste:

o CrediAmigo está presente em 1.420 municípios da área de atuação do Banco (Região Nordeste e Norte dos estados de Minas Gerais e Espírito Santo). O atendimento se dá por meio de uma estrutura logística que dispõe de 170 agências e 26 postos de atendimento aos clientes. 
Contudo, é importante destacar que a política de microcrédito do Banco Gremeen, diferente do CrediAmigo, não é considerada como microcrédito produtivo orientado, justamente pelo fato de que o agente de credito lá tem a função de explicar como funciona o sistema de financiamento do Banco, mas não está autorizado a dar instruções com relação ao negócio.

Assim, percebe-se que as políticas de microcrédito, especialmente a do CrediAmigo vem contribuindo ao longo dos anos com o desenvolvimento de várias cidades do Nordeste, assim essas ações podem auxiliar na diminuição da pobreza nessa região.

Fisicamente a estrutura do Banco não é muito grande composto por volta de 300 agências, mas mesmo não sendo muito grande consegue atender todo 1990 municípios, principalmente no microcrédito que é para o pequeno empreendedor. Isso também é possível, porque o Banco participa do Fundo Constitucional do Nordeste - FNE.

O Fundo Constitucional do Nordeste foi criado em 1988 pela Constituição Federal de 1988 e efetivamente regulamentado pela Lei de no 7.827 , de 27 de setembro e 1989. Nesse sentido, o FNE financia boa parte das atividades do banco e isso faz com que esse dinheiro chegue aos 1990 municípios os quais vivem justamente da agricultura familiar.

Segundo o presidente do Banco, com o auxílio do FNE o Banco funciona mais que um banco maximizador de lucro passando a ser maximizador de resultados.

Ou seja, são com os recursos aplicados no FNE que giram em torno de 13 bilhões que chegam basicamente para as famílias que mais precisam e para as empresas. Isso pode significar que o Banco possui capacidade para novos investimentos e mesmo sendo um banco de Desenvolvimento e atendendo justamente um segmento de mercado que o próprio mercado não tem interesse em atender por acreditarem que em tese esses clientes apresentam mais risco.

$\mathrm{Na}$ verdade, o banco de desenvolvimento surge justamente para corrigir essa falha de mercado conseguindo ofertar a esses clientes e empresas diversos serviços que podem gerar emprego e renda. E de certa forma com essas os governos 
conseguem de certa forma transforma a vida dessas pessoas mais pobres colaborando para que elas mesmas consigam quebra o ciclo de pobreza não dando o peixe mais ensinando a cada pequeno empreendedor a utilizar de sua criatividade e esforço para ser empreendedor e pesca o seu próprio peixe.

Assim o microcrédito no banco do Nordeste é uma experiência vitoriosa, tendo em vista que no mercado brasileiro o BNB é líder. Segundo informações no site do banco, hoje só no microcrédito é aplicado em torno de 9 bilhões segundo o presidente do banco, ou seja, é um banco que investe na indústria, no comercio na agricultura e nas pequenas iniciativas do microcrédito gerando renda e aumentando os empregos formais diariamente.

Ainda de acordo com o Banco, são realizadas em torno de 16 mil operações bancarias. Assim essas operações são consideradas um credito mais seguro em torno do risco contrapondo com o mercado que acha que a princípio emprestando dinheiro aos mais pobres seria uma operação com maior risco.

Todavia mesmo assim ele consegue ter lucros não se comparado aos os Bancos do sistema financeiro tradicional, mas sobretudo, ele apresenta lucro até mesmo para sua proporia sustentabilidade.

E apesar da existência de risco no Banco de Desenvolvimento os benefícios advindos do banco tem um impacto muito positivo para a sociedade, ou seja, ele consegue aumentar a renda das famílias e tornar essas empresas mais competitivas porque fazendo isso as empresas prosperam gerando mais renda e consequentemente gerando mais empregos.

Um dos fatores do programa CrediAmigo que proporciona o sucesso é a maneira como são realizadas as operações que se dão por meio do aval solidário. Assim como é feito em outros países, como na Índia, ou seja, o microcrédito não é fornecido de maneira individual. Primeiramente é formado um grupo, e depois escolhe-se um representante para que ele possa solicitar os recursos ao Banco.

O sistema de cobrança, ao contrário é realizado não individualmente, mas é dirigido ao grupo e isso garante uma taxa de inadimplência muito baixa, muito mais baixa que as outras atividades cobradas pelo Banco, assim como os valores são 
baixos mesmo com a atual crise enfrentada pelo país tanto política quanto econômica, conforme relatado pelo presidente do BNB "pode-se dizer que a crise não gerou inadimplência nessas operações".

Isso pode ser explicado tendo em vista que o valor e o custo para esses clientes não são muito alto e o pouco que é emprestado faz toda a diferença para eles.

Assim, é possível perceber o quanto as ações do BNB podem colaborar com o aumento de emprego e renda e o quanto tudo isso desempenha um papel importante na economia do país. Pois as ações que são desempenhas pelo setor público podem também ser refletidas no setor privado.

Nesse sentido, são necessárias ações em conjunto para que cada vez mais as políticas de microcrédito cheguem para as pessoas que realmente necessitam dela, sobretudo nas regiões do Nordeste, tendo em vista que é onde está localizada a parte mais pobre do Brasil, por isso sua base econômica mesmo com os avanços ainda é muito incipiente.

Os estudos nos mostram que no final dos anos 2000 o Nordeste teve um crescimento de emprego e renda, entretanto esse crescimento pode ser explicado segundo alguns especialistas mais basicamente porque se tinha uma combinação favorável de inflação baixa e um ganho de aporte de recursos financeiros por meio de programas de transferência de renda e da formalização do mercado de trabalho.

Assim, ainda hoje com todas as melhorias disponibilizadas pelo microcrédito e pelos programas de transferência de renda e da formalização de empregos no mercado de trabalho a contribuição do Nordeste com relação ao Produto Interno bruto-PIB ainda é muito pouco diante do potencial de crescimento do Nordeste. Talvez hoje isso possa representam um grande desafio para o governo.

O microcrédito possibilitaria, então, o rompimento do ciclo de pobreza de uma maneira eficiente, sem redistribuição drástica de renda ou necessidade de intervenção estatal (BATEMAN, 2012). 
Porém, alguns autores defendem que apesar das políticas de microcrédito melhorarem a vida das pessoas de baixa renda, os programas não conseguem tirar as pessoas dessa condição.

Assim eles apontam um outro assunto que não é tema desse estudo, será explanado apenas para exemplificação.

Analisando o caso latino-americano, sobretudo com relação ao sistema capitalista, autores como De Soto (1986), afirmam que o capitalismo não havia se desenvolvido plenamente nesta região, porque os mais pobres não conseguiam gerar capital por não terem acesso ao crédito.

Ainda segundo o autor, este acesso, por sua vez, era bloqueado por falta de direitos de propriedade bem definidos: os pobres tinham ativos, mas não conseguiam utilizá-los por não terem sua posse legal. Assim se eles tivessem acesso ao crédito de certa maneira iriam gerenciar o capital se beneficiando então do sistema capitalista plenamente.

Para finalizar, se analisarmos o caso brasileiro, podemos perceber que realmente essa questão levantada por De Soto faz parte da nossa realidade. Assim - Brasil possui vários desafios para serem enfrentados além daqueles já mencionados pelos autores.

\section{Metodologia}

Para a realização deste trabalho será utilizado o método descritivo para avaliar os dados apresentados pelo Banco do Nordeste, com o programa CrediAmigo fazendo referência dos anos de 2000 a 2010. Desde modo, para sustentar essa análise foi realizado um estudo bibliográfico com levantamento de dados secundários, que irão sustentar a análise de dados do trabalho realizada. Dessa forma a escolha do material foi direcionada para o objetivo proposto neste trabalho.

Desta maneira foi realizada uma análise comparativa da política de microcrédito do CrediAmigo de uma década no tocante à inclusão social e econômica das pessoas que são excluídas do sistema tradicional adotados pelos 
bancos. Nesse sentido, analisaremos agora os dados abaixo levando em consideração o resultado do programa e a evolução dos dados de 2000 a 2010, assim segue:

a) Carteira ativa;

\section{Tabela 2}

\begin{tabular}{|r|r|}
\hline ANOS & \multicolumn{1}{|l|}{ R\$ (MILHÕES) } \\
\hline 2000 & 16,9 \\
\hline 2001 & 49,8 \\
\hline 2002 & 71,9 \\
\hline 2003 & 85,5 \\
\hline 2004 & 106,7 \\
\hline 2005 & 136,3 \\
\hline 2006 & 170,6 \\
\hline 2007 & 234,7 \\
\hline 2008 & 362,2 \\
\hline 2009 & 501,7 \\
\hline 2010 & 742,6 \\
\hline
\end{tabular}

Fonte: Relatórios do CrediAmigo de 2000 a 2010 


\section{Gráfico 1}

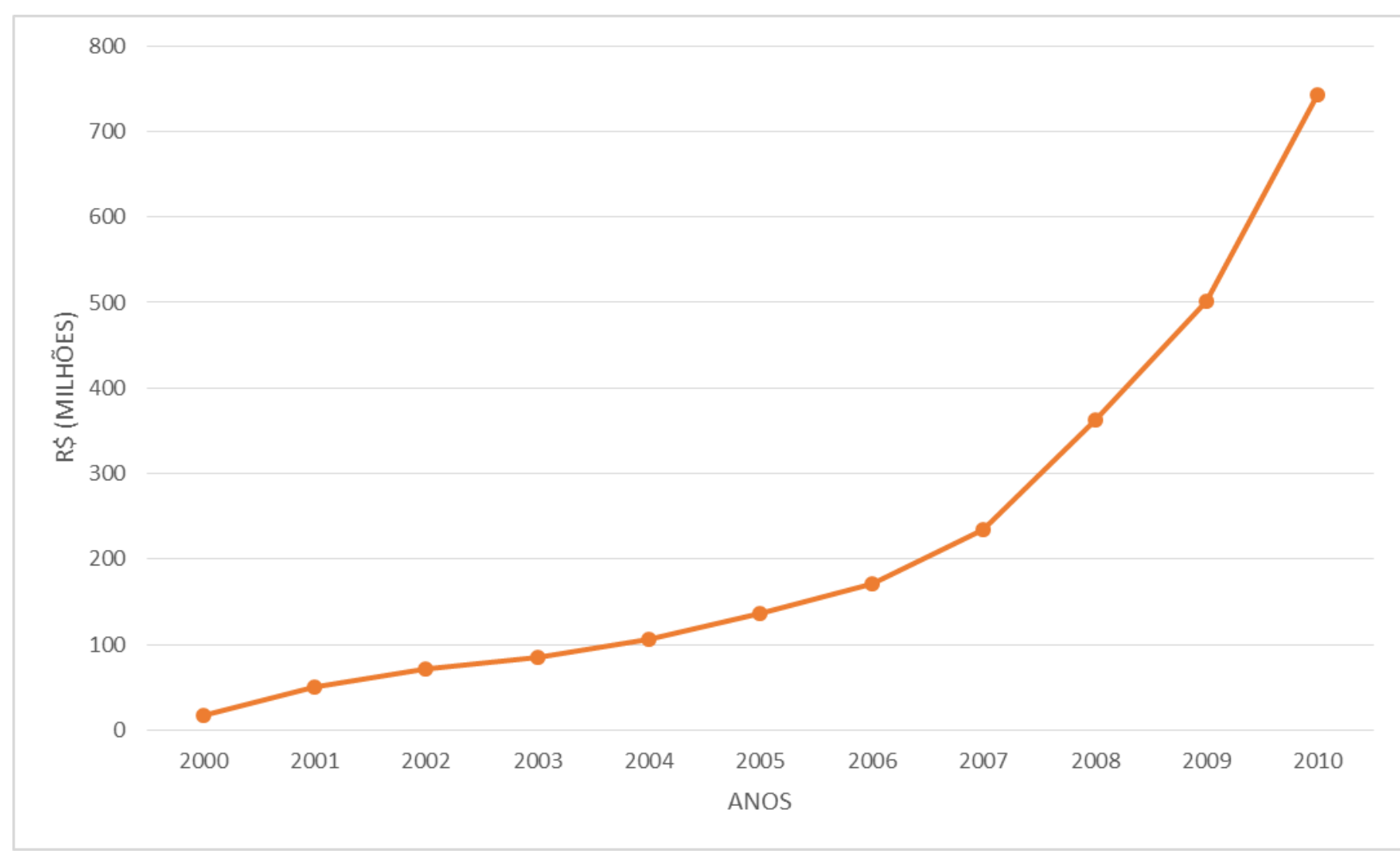

Fonte: Relatórios do CrediAmigo de 2000 a 2010

b) Clientes ativos;

Tabela 3

\begin{tabular}{|r|r|}
\hline ANOS & MIL (CLIENTES) \\
\hline 2000 & 57.967 \\
\hline 2001 & 85.309 \\
\hline 2002 & 118.955 \\
\hline 2003 & 138.497 \\
\hline 2004 & 162.868 \\
\hline 2005 & 195.378 \\
\hline 2006 & 235.729 \\
\hline 2007 & 299.975 \\
\hline 2008 & 400.413 \\
\hline 2009 & 528.792 \\
\hline 2010 & 737.826 \\
\hline &
\end{tabular}


Fonte: Relatórios do CrediAmigo de 2000 a 2010

\section{Gráfico 2}

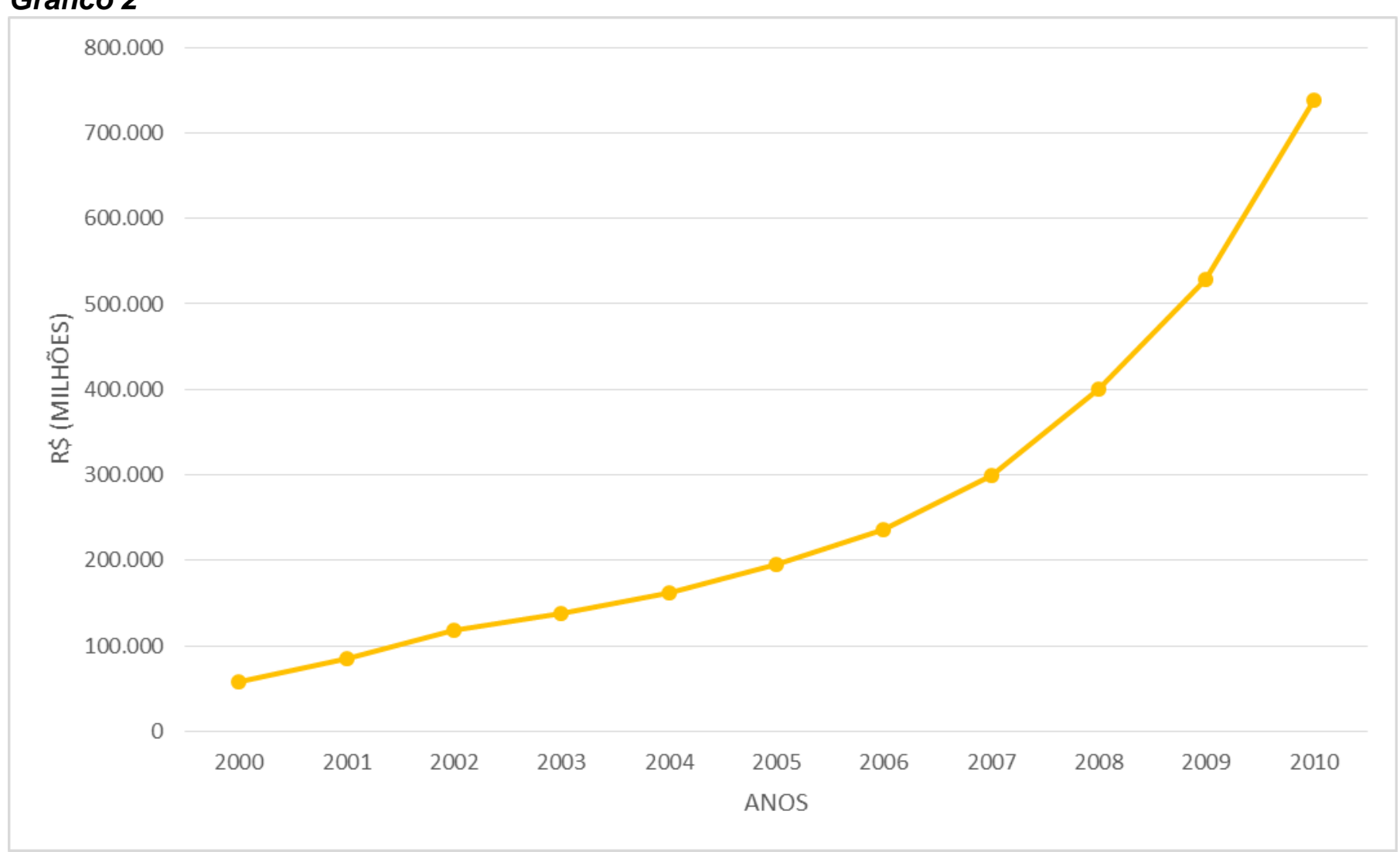

Fonte: Relatórios do CrediAmigo de 2000 a 2010

Sobre a carteira ativa temos na década quando analisamos as medidas de tendência central temos um volume total de $R \$ 2.478,9$ bilhões de reais, uma média de $R \$ 247,89$ milhões de reais e uma mediana de $R \$ 136,3$ milhões de reais. Dessa forma, as medidas de dispersão da década em tela se mostram com valor mínimo de $R \$ 16,9$ milhões de reais em 2000 , valor máximo $R \$ 742,6$ milhões de reais em 2010.

De dez/2002 a dez/2003, registrou um crescimento de 18,76\% na carteira ativa e $16,43 \%$ de clientes ativos. O CrediAmigo terminou o ano de 2003 com uma base de 138,4 mil clientes (carteira ativa da ordem de $\mathrm{R} \$ 85,5$ milhões de reais). Em 2004, o resultado indica melhoria na qualidade da carteira, visto que ocorreu no período analisado um aumento de $22 \%$ na carteira de empréstimos saindo de $R \$$ 85,5 milhões de reais para $\mathrm{R} \$ 106,7$ milhões. 
Em 2005, aos 195.378 clientes ativos, foram emprestados na carteira ativa um montante de $R \$ 136,3$ milhões de reais. Em 2006, dos 690.415 empréstimos desembolsados atingiram a marca de $\mathrm{R} \$ 170,6$ milhões de reais. Em 2007, dos 824.782 empréstimos desembolsados, gerando um montante de $R \$ 234,7$ milhões de reais, isso significa um aumento de $37,5 \%$ em relação ao ano anterior.

O CrediAmigo cumpre, de forma sustentável, sua missão de ofertar serviços financeiros e orientação empresarial aos clientes. Dessa forma atingiu em 2008 o número de clientes ativos de 400.413 e um montante na carteira ativa no valor de $\mathrm{R} \$$ 362,2 milhões de reais.

Em dezembro de 2009, o Programa estava presente em 1.773 municípios, por meio de 258 pontos de atendimento, nesse período a quantidade de clientes ativos era de 528.792 e um volume na carteira ativa de $\mathrm{R} \$ 501,7$ milhões de reais. Em suma, em dezembro de 2010 o Programa contava com 314 unidades de atendimento, em 1.829 municípios e já atuando em outras regiões do país, com essa expansão tivemos um número de clientes ativos de 737.826 mil e um valor de $R \$$ 742,6 milhões de reais, logo em uma década tivemos um aumento da carteira ativa em $4394 \%$ aproximadamente.

c) Empréstimos desembolsados (Milhões)

\section{Tabela 4}

\begin{tabular}{|r|r|}
\hline ANOS & R\$ (MILHÕES) \\
\hline 2000 & 126 \\
\hline 2001 & 201 \\
\hline 2002 & 281 \\
\hline 2003 & 368,2 \\
\hline 2004 & 441 \\
\hline 2005 & 548 \\
\hline 2006 & 640 \\
\hline 2007 & 794 \\
\hline 2008 & $1.087,50$ \\
\hline 2009 & $1.499,20$ \\
\hline 2010 & $2.066,30$ \\
\hline
\end{tabular}


Gráfico 3

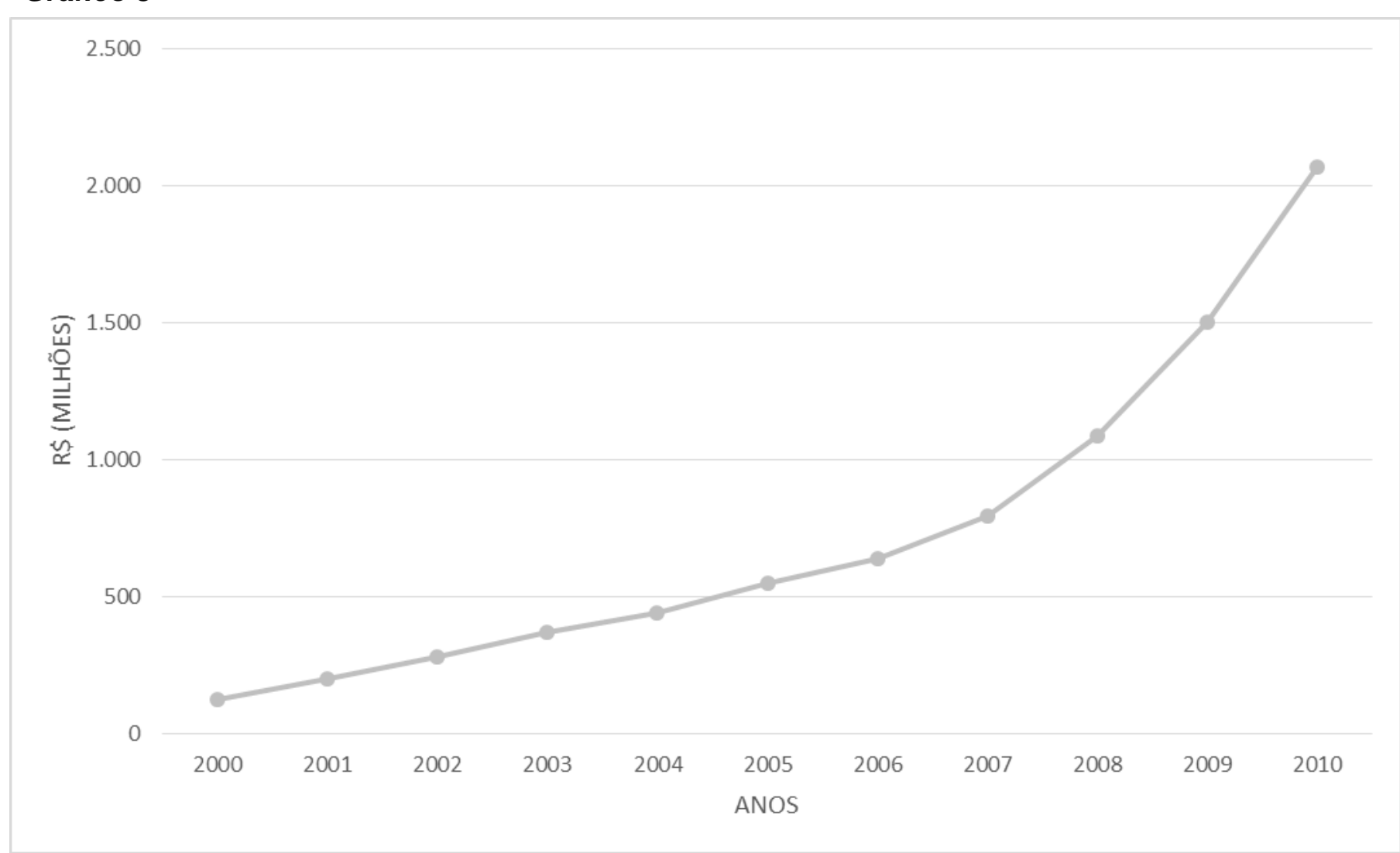

Fonte: Relatórios do CrediAmigo de 2000 a 2010

d) Empréstimos desembolsados (Quantidade);

Tabela 5

\begin{tabular}{|r|r|}
\hline \multicolumn{1}{|l|}{} & \multicolumn{2}{l}{$\begin{array}{l}\text { MIL } \\
\text { (EMPRESTIMOS) }\end{array}$} \\
\hline 2000 & 165.916 \\
\hline 2001 & 257.847 \\
\hline 2002 & 347.259 \\
\hline 2003 & 438.810 \\
\hline 2004 & 507.807 \\
\hline 2005 & 595.742 \\
\hline 2006 & 690.415 \\
\hline 2007 & 824.782 \\
\hline 2008 & 1.009 .594 \\
\hline 2009 & 1.259 .594 \\
\hline 2010 & 1.632 .482 \\
\hline
\end{tabular}


Fonte: Relatórios do CrediAmigo de 2000 a 2010

\section{Gráfico 4}

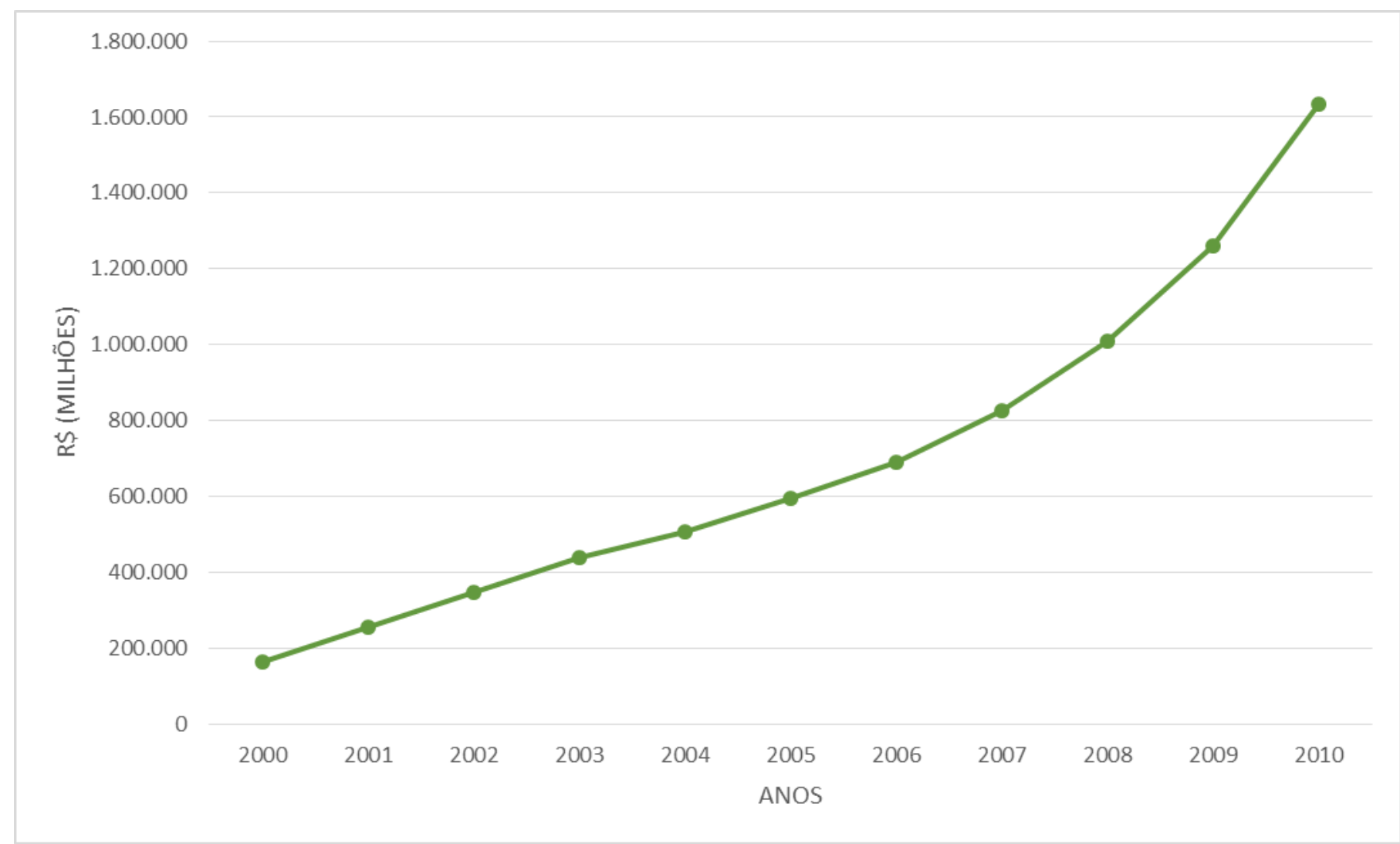

Fonte: Relatórios do CrediAmigo de 2000 a 2010

e) Valor médio dos empréstimos em reais;

\section{Tabela 6}

\begin{tabular}{|r|r|}
\hline ANOS & R\$ (REAIS) \\
\hline 2000 & 700 \\
\hline 2001 & 734 \\
\hline 2002 & 762 \\
\hline 2003 & 846,81 \\
\hline 2004 & 868,28 \\
\hline 2005 & 920,26 \\
\hline 2006 & 926,41 \\
\hline 2007 & 965,99 \\
\hline 2008 & $1.077,59$ \\
\hline 2009 & $1.190,23$ \\
\hline 2010 & $1.265,75$ \\
\hline
\end{tabular}

Fonte: Relatórios do CrediAmigo de 2000 a 2010 


\section{Gráfico 5}

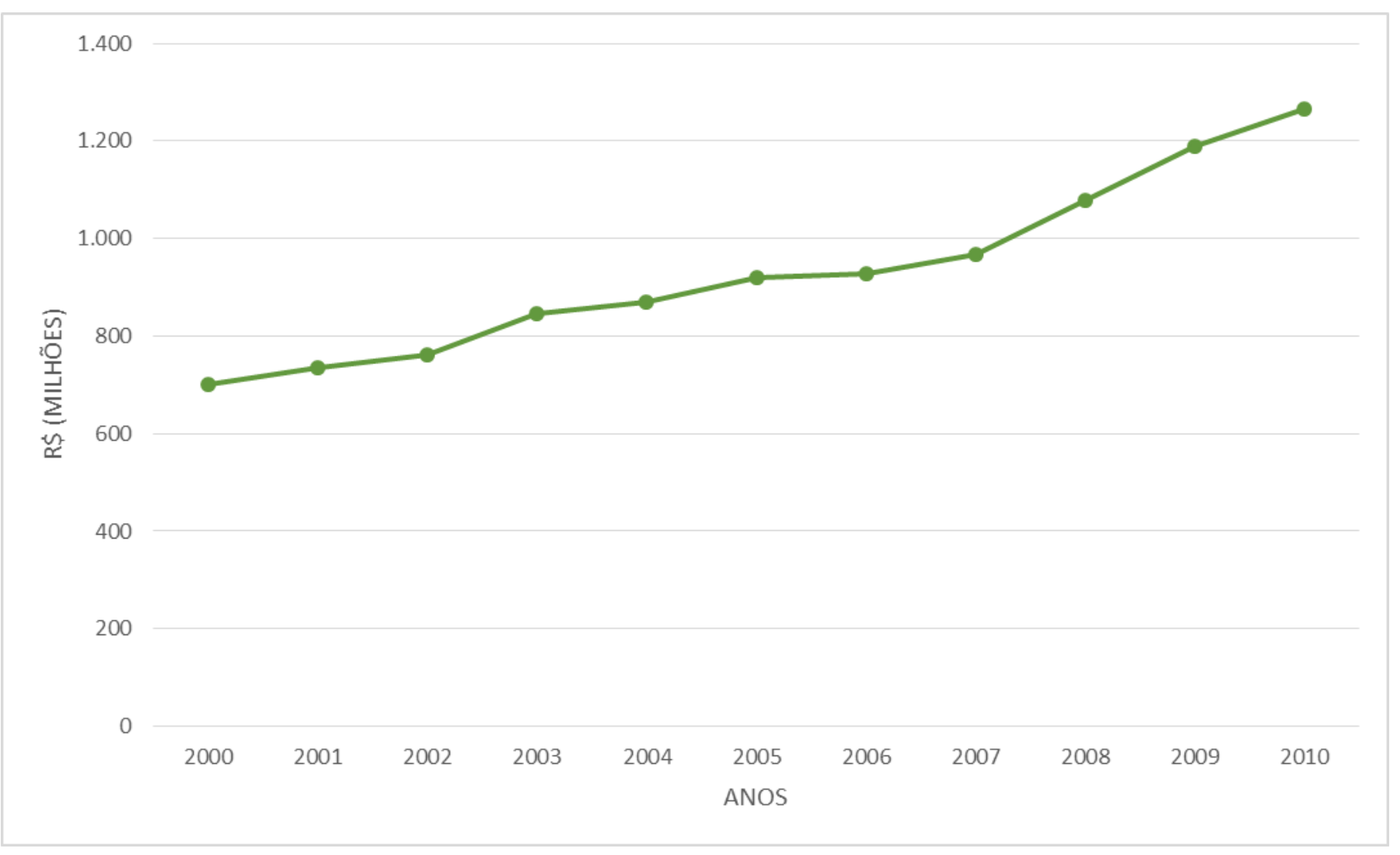

Fonte: Relatórios do CrediAmigo de 2000 a 2010

Sobre os empréstimos desembolsados em quantidade e milhões de reais temos na década quando analisamos as medidas de tendência central um volume total de $R \$ 8.052,2$ bilhões de reais, uma média de $R \$ 732,01$ milhões de reais e uma mediana de $\mathrm{R} \$ 548$ milhões de reais. Dessa forma, as medidas de dispersão da década em tela se mostram com valor mínimo de $R \$ 126$ milhões de reais em 2000, valor máximo $R \$ 2.066,30$ bilhões de reais em 2010.

Os empréstimos valores e a quantidade de empréstimos não param de aumentar ano a ano, tendo o programa acumulado de $\mathrm{R} \$ 125,9$ milhões financiados através de 165,9 mil operações de empréstimo em 2000. Os indicadores globais de desempenho do CrediAmigo mostram que o Programa aplicou, em 2001, R\$ 201 milhões em 257,9 mil operações de crédito. O crescimento de $56,7 \%$ da carteira ativa - que alcançou $R \$ 49,8$ milhões em dezembro - significou um crescimento médio trimestral de $12,07 \%$, superior, portanto, à referência ideal estabelecida pelo Banco Mundial, de 10\%. 
Em 2002, o total de aplicações somou $R$ \$ 281 milhões através de 347 mil operações de microcrédito, saindo de uma média de 233 operações realizadas por dia útil em 1998, para uma média de 1.315 em 2002. Em 2003, o total de aplicações somou $\mathrm{R} \$ 368,2$ milhões através de 434,8 mil operações de microcrédito, saindo de uma média de 233 operações realizadas por dia útil em 1998, para uma média diária de 1.647, em 2003.

O volume de empréstimos realizados em 2004 foi da ordem de $\mathrm{R} \$ 440,9$ milhões, correspondendo a um crescimento de $19,74 \%$ em relação a 2003 quando foram emprestados $\mathrm{R} \$ 368,2$ milhões. Em 2005, dos 595.742 empréstimos desembolsados, $82,16 \%$ foram de até $R \$ 1.000,00$.

Os empréstimos são adequados ao perfil da atividade do cliente e têm beneficiado os empreendedores da base da pirâmide. Em 2006, dos 690.415 empréstimos desembolsados, $82,5 \%$ foram de até $R \$ 1.000,00$, foram emprestados um montante de $\mathrm{R} \$ 640$ milhões.

Os empréstimos são adequados ao perfil da atividade do cliente e têm beneficiado os empreendedores da base da pirâmide. Em 2007, dos 824.782 empréstimos desembolsados, $78,5 \%$ foram de até $R \$ 1.000,00$, foram emprestados um montante de $\mathrm{R} \$ 794$ milhões.

Em 2008, dos mais de 1 milhão de empréstimos desembolsados, 70,07\% foram de até $R \$ 1.000,00$, foram emprestados um montante de $R \$ 1.087,50$ bilhões.

Em dezembro de 2009, totalizam 92\% a quantidade de operações com valores que variam de $R \$ 100$ a $R \$ 3.000$, demonstrando a efetividade como montante

$\mathrm{R} \$ 1.499,20$ bilhões uma quantidade de 1.259 .594 empréstimos desembolsados. Dessa forma, em dezembro de 2010 o Programa contava com a maior parte das operações é de baixo valor, $92 \%$ até $R \$ 3.000,00$, indicando a efetividade das ações com $\mathrm{R} \$ 2.066,30$ bilhões através de 1.632 .482 milhão de operações de microcrédito. Por derradeiro, os resultados demonstram o crescimento do CrediAmigo, com excelentes indicadores de alcance de produtividade e sustentabilidade. Com índices 
de inadimplência e perda entre os mais baixos do setor, o CrediAmigo se destaca como política de inclusão social e financeira.

f) Índice de inadimplência *;

\section{Tabela 7}

\begin{tabular}{|r|r|}
\hline ANOS & Percentual \\
\hline 2000 & $1,76 \%$ \\
\hline 2001 & $2,27 \%$ \\
\hline 2002 & $2,09 \%$ \\
\hline 2003 & $1,81 \%$ \\
\hline 2004 & $0,84 \%$ \\
\hline 2005 & $0,84 \%$ \\
\hline 2006 & $0,73 \%$ \\
\hline 2007 & $0,81 \%$ \\
\hline 2008 & $1,13 \%$ \\
\hline 2009 & $1,16 \%$ \\
\hline 2010 & $0,72 \%$ \\
\hline
\end{tabular}

Fonte: Relatórios do CrediAmigo de 2000 a 2010

\section{Gráfico 6}

$2,50 \%$

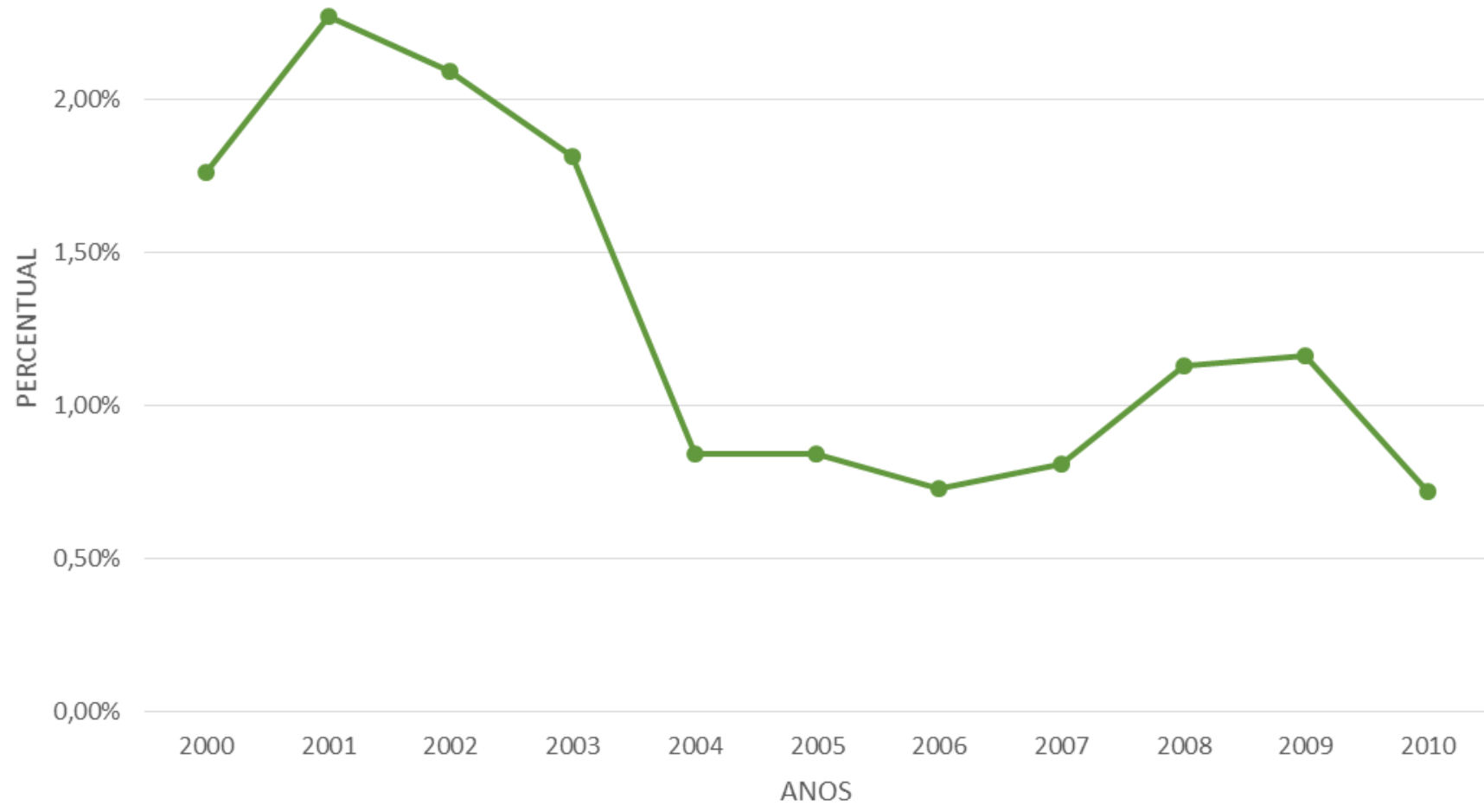


Fonte: Relatórios do CrediAmigo de 2000 a 2010

g) Índice de perdas*

\section{Tabela 8}

\begin{tabular}{|r|r|}
\hline ANOS & Percentual \\
\hline 2000 & $1,43 \%$ \\
\hline 2001 & $5,77 \%$ \\
\hline 2002 & $3,79 \%$ \\
\hline 2003 & $3,30 \%$ \\
\hline 2004 & $1,30 \%$ \\
\hline 2005 & $0,85 \%$ \\
\hline 2006 & $0,89 \%$ \\
\hline 2007 & $0,73 \%$ \\
\hline 2008 & $0,73 \%$ \\
\hline 2009 & $1,00 \%$ \\
\hline 2010 & $0,52 \%$ \\
\hline
\end{tabular}

*Valores em atraso superior a 90 dias, apresentados no ano

corrente, em relação à Carteira de Empréstimos e Financiamentos

\section{Gráfico 7}

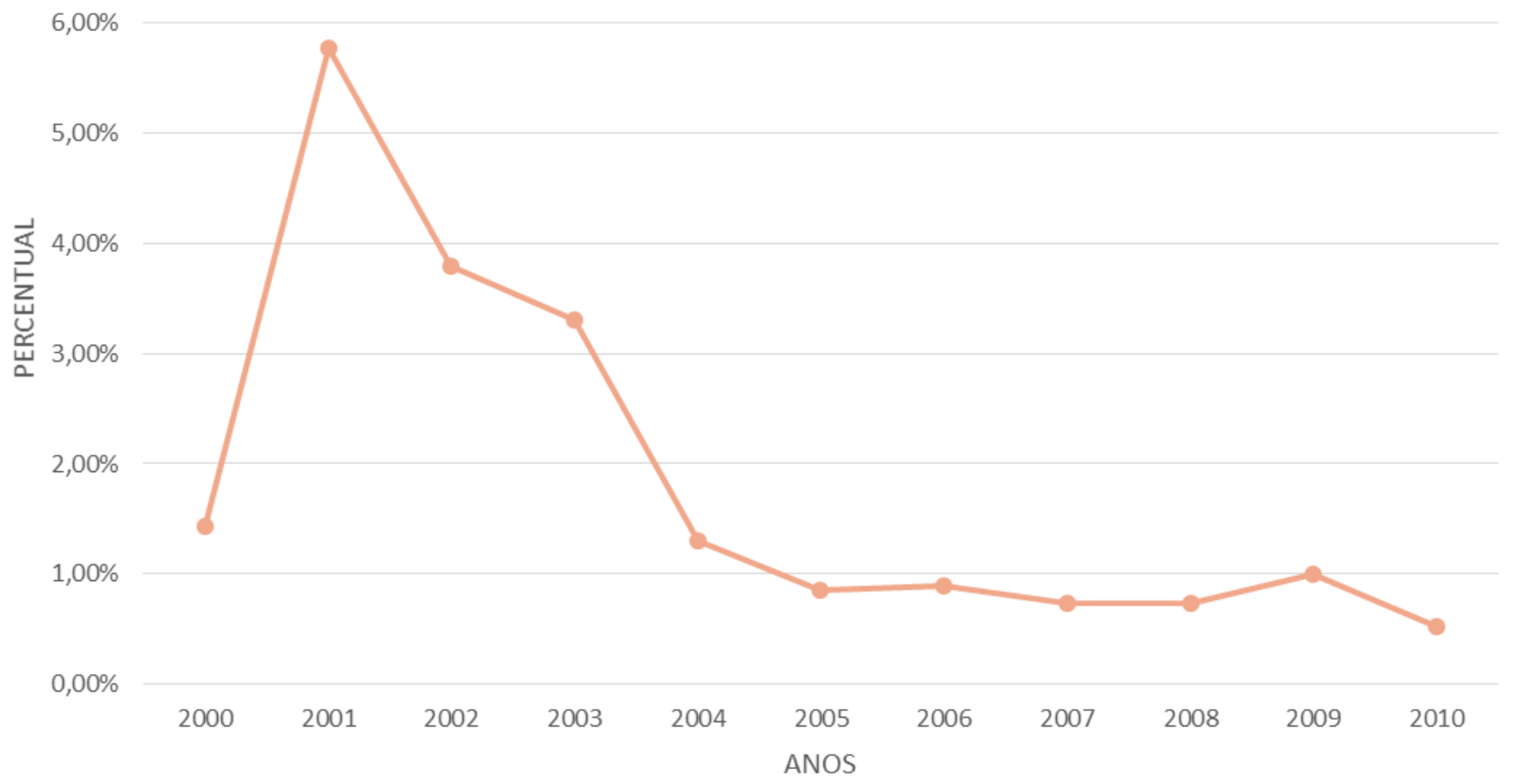


Do mês de 31 de dezembro de cada ano.

Fonte: Relatórios do CrediAmigo de 2000 a 2010

Fonte: Relatórios do CrediAmigo de 2000 a 2010

A inadimplência é rigidamente controlada não sendo possível prorrogação ou rolagem de dívidas. A pontualidade é alta, por pressões morais e pela necessidade de continuidade do acesso ao crédito. Nestes casos, são analisados relatórios semanais e mensais de inadimplência e média de clientes novos, além de avaliados, mensalmente, os indicadores, com gráficos e recomendações sobre o desempenho operacional. Semestralmente, é realizado também um acompanhamento da evolução semestral dos indicadores, dando suporte aos gestores para ações de maior prazo.

Em 2000, o trabalho de monitoração foi feito por dois profissionais em visitas periódicas, tanto a unidades operativas como a clientes. Foram visitadas, no período, 35 unidades, ou $32,4 \%$ do total, avaliadas em critérios constantes do ranking de risco, como inadimplência, produtividade por assessor, carteira ativa, valor médio dos empréstimos, despesas administrativas e resultado financeiro. Em 2000, a diminuição do risco mostrada pelos indicadores pode ser explicada pela melhora da qualidade na concessão de crédito em virtude de maior experiência e melhor preparação dos assessores de crédito.

Em 2001, a maior parte $(74,51 \%)$ das operações com atraso foi contratada com periodicidade mensal de pagamento e quase a metade $(47,62 \%)$ teve prazo total de até 90 dias para liquidação. As mulheres são responsáveis por $47 \%$ dos contratos em atraso. Mais de um quarto $(27,08 \%)$ da inadimplência de $2,27 \%$ ocorre entre os clientes novos, diminuindo à medida que aumenta o número de renovações, conforme ilustrado no gráfico 6.

A redução é consequência do acompanhamento ao cliente e da assessoria empresarial constante. A carteira de risco (30 dias) variou em torno de $4 \%$ durante o ano de 2001, fechando o período em 3,68\%. O percentual ficou bem abaixo do limite de $8 \%$ estabelecido como referência pelo contrato do Banco Mundial. Em 2001, o aumento do risco mostrado pelos indicadores no gráfico de perdas pode ser explicado em parte pela redução da atividade econômica (2001 foi um ano de racionamento de energia) e pela 
expansão da carteira, existindo um custo de aprendizagem relativo aos novos assessores.

Em 2002, em função dos esforços realizados para melhorar a qualidade da carteira em 2002, os saldos com atraso superior a 30 dias (carteira de risco) diminuíram durante o ano, passando de 3,20\% no início do período para 2,39\% no mês de dezembro. Os empréstimos do CrediAmigo são classificados em função dos dias de atraso e provisionados de acordo com os percentuais estabelecidos pelo Banco Central. O índice de inadimplência representa a relação percentual dos valores não reembolsados, com atraso a partir de um dia, encerrando-se em 2002 em 2,09\%. No mesmo ano, a taxa de perdas a relação percentual dos valores inadimplentes (em atraso) acima de 90 dias não recuperados em relação à carteira. Com base nas amostras selecionadas e testadas, a carteira, da forma como é informada pela instituição financeira, é consistente. Existem provisões suficientes para possíveis perdas nas operações de microcréditos. A partir 2003, outro diferencial foi a possibilidade de um cliente que já faz parte de um grupo solidário, poder receber individualmente, empréstimo complementar para capital de giro.

Ou seja, um cliente do CrediAmigo tem a possibilidade de contratar até três operações simultaneamente, sendo uma para aquisição de máquinas e equipamentos (investimento fixo) e duas para capital de giro (uma através do grupo solidário e outra individualmente), acredita-se que iniciativas como essa ajudam a conter os índices de inadimplência e perdas. A taxa de inadimplência do CrediAmigo tem tido, ao longo de sua existência, um comportamento acentuado de queda, chegando ao índice de $0,84 \%$ ao final de 2004.

Em relação a 2003, houve uma redução significativa do índice de perda, passando de 4,7\% em 2003 para 1,9\% em 2004, o que representa uma redução deste índice de $58,5 \%$. O valor bruto de perda foi reduzido em mais de $50 \%$, desse aumento de $18,5 \%$ na carteira média ativa. A Provisão de Perdas é realizada com base na Resolução do Banco Central do Brasil no 2.682. Os resultados demonstram o crescimento do CrediAmigo, com excelentes indicadores de alcance, produtividade e sustentabilidade. Com índices de inadimplência e perda entre os mais baixos do setor, o CrediAmigo se destaca como política de inclusão social e financeira se analisados os períodos de 2005 até 2010 os números são extraordinários. 
h) Perfil dos clientes por gênero

\section{Tabela 9}

\begin{tabular}{|r|r|r|}
\hline ANOS & FEMININO & MASCULINO \\
\hline 2000 & 49,5 & 50,5 \\
\hline 2001 & 50 & 50 \\
\hline 2002 & 51 & 49 \\
\hline 2003 & 63 & 47 \\
\hline 2004 & 61 & 39 \\
\hline 2005 & 61 & 39 \\
\hline 2006 & 62 & 38 \\
\hline 2007 & 64 & 36 \\
\hline 2008 & 65 & 35 \\
\hline 2009 & 65 & 35 \\
\hline 2010 & 65 & 35 \\
\hline
\end{tabular}

Fonte: Relatórios do CrediAmigo de 2000 a 2010

\section{Gráfico 8}

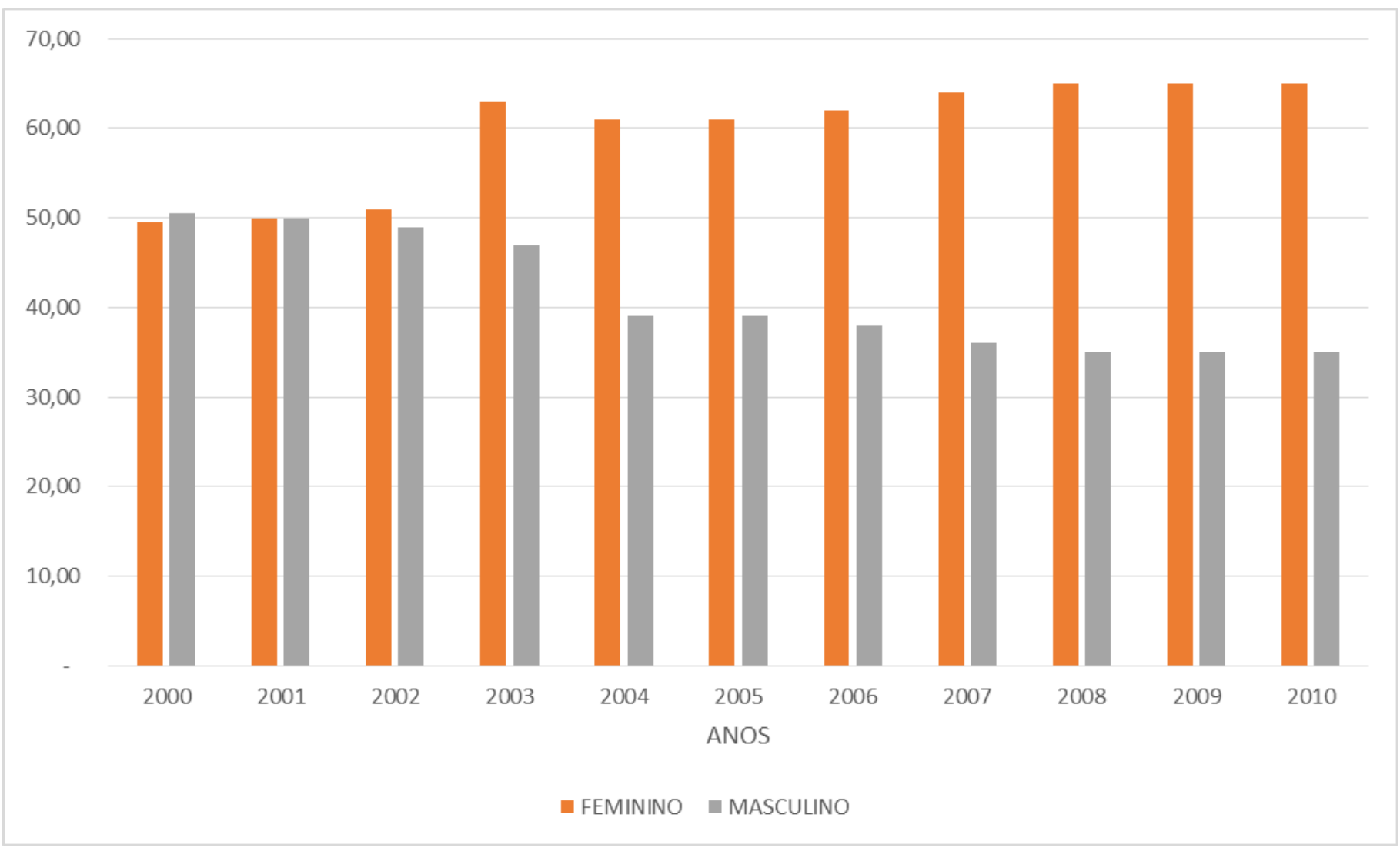


Fonte: Relatórios do CrediAmigo de 2000 a 2010

No ano 2000, os clientes do CrediAmigo nas regiões metropolitanas e no interior dos Estados apresentavam características distintas conforme a localização dos microempreendimentos, se em regiões metropolitanas ou no interior dos Estados, nas quais o perfil das clientes femininas $48,8 \%$ no interior, $51,1 \%$ na região metropolitana e $49,5 \%$ do programa.

Em 2001, a participação da mulher no total de contratos praticamente não divergiu, girando em torno dos 50\% e evidenciando que a abrangência do Programa entre o público feminino fica a contento independentemente da localização.

Em 2002 e 2003, houve equilíbrio na participação de homens e mulheres (50,8\%). Em consonância com a experiência de microcrédito no mundo, as mulheres são maioria no CrediAMIGO, representando cerca de $61 \%$ do total de clientes atendidos.

A participação feminina cresceu significativamente nos dois últimos anos. Em 2000 a quantidade de clientes do sexo masculino superava a de clientes mulheres, realidade que mudou a partir de 2002.

Duas clientes do CrediAmigo foram premiadas em 2005: Maria Mery Vieira Silva (Unidade de Bezerra de Menezes - Posto de Caucaia - CE) foi a primeira colocada na categoria comércio, recebendo a premiação de $R \$ 6.000,00$; e Maria José de Oliveira (Unidade de Bezerros-PE), a terceira colocada na categoria indústria, com premiação de $\mathrm{R} \$ 2.450,00$. Em 2005 as mulheres eram maioria no CrediAMIGO, representando cerca de $61 \%$ do total de clientes atendidos, já em 2006 foi para $62 \%$.

Os clientes são, em sua maioria, pessoas que trabalham por conta própria, em negócios de pequeno porte, e se caracterizam por dispor de um mínimo de capital. Em 2007 o perfil das mulheres foi 64\%. De 2008 a 2010 a participação da mulher no total de contratos praticamente não divergiu, girando em torno dos $65 \%$. 
i) Setor das atividades atuantes;

Tabela 10

\begin{tabular}{|r|r|r|r|}
\hline \multicolumn{1}{|l|}{ ANOS } & COMÉRCIO & INDÚSTRIA & SERVIÇOS \\
\hline 2000 & 87,8 & 7,3 & 5,7 \\
\hline 2001 & 84,6 & 9,7 & 5,7 \\
\hline 2002 & 81 & 14 & 5 \\
\hline 2003 & 91 & 4 & 5 \\
\hline 2004 & 92 & 3 & 5 \\
\hline 2005 & 92 & 3 & 5 \\
\hline 2006 & 92 & 3 & 5 \\
\hline 2007 & 92 & 2 & 6 \\
\hline 2008 & 92 & 3 & 5 \\
\hline 2009 & 93 & 1 & 6 \\
\hline 2010 & 92 & 2 & 6 \\
\hline
\end{tabular}

Fonte: Relatórios do CrediAmigo de 2000 a 2010

\section{Gráfico 9}

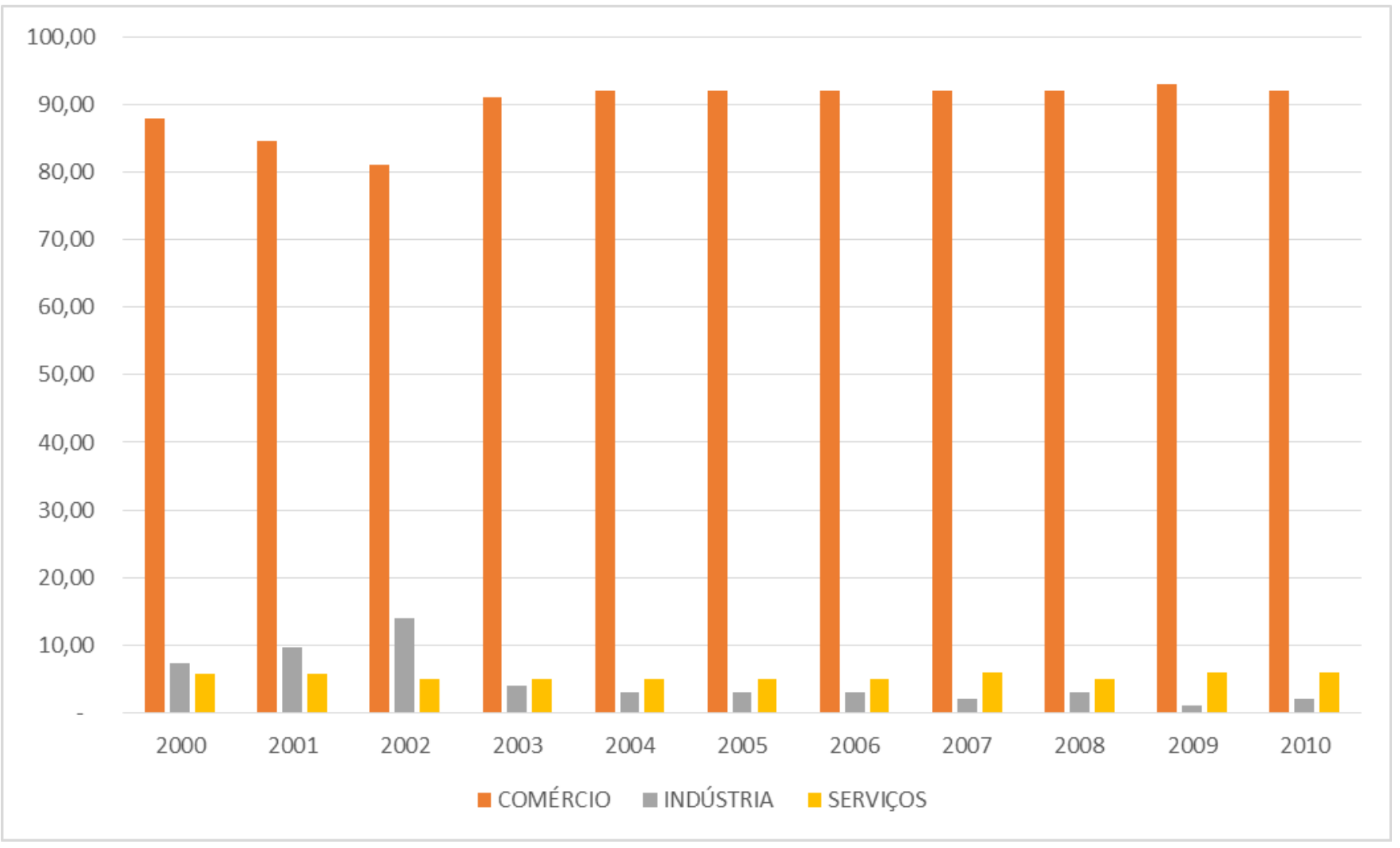

Fonte: Relatórios do CrediAmigo de 2000 a 2010 
Por faixa de valor e setor de atividade na indústria: marcenaria, sapataria, carpintaria, artesanato, alfaiataria, gráfica, padaria, produção de alimentos, fabricante de uma infinidade de produtos de consumo, etc. Comércio: vendedores em geral, mercadinhos, papelarias, armarinhos, bazares, farmácias, armazéns, restaurantes, lanchonetes, ambulantes, feirantes, pequenos lojistas, açougueiros, vendedores de cosméticos, etc. Serviços: salões de beleza, oficinas mecânicas, borracharias, tinturarias, lavagens em geral, prestadores de serviços autônomos etc.

Em 2000, caracterizou-se por uma concentração dos micronegócios no setor de comércio com $87,8 \%$, indústria $7,3 \%$ e serviços com $5,7 \%$. Embora continue como atividade mais representativa no universo de clientes do CrediAmigo, os microempreendimentos do setor de comércio registraram um ligeiro decréscimo em sua participação em 2001, passando de $87 \%$ para $84,6 \%$, o decréscimo foi contrabalançado por um crescimento equivalente na participação das microempresas do ramo industrial.

Em 2002, os empreendimentos de comércio (81\%) receberam a maior quantidade de recursos do CrediAmigo ( $R \$ 227,6$ milhões), seguidos da indústria (14\%), com $R \$ 39,3$ milhões e pelo segmento de serviços (5\%) com $R \$ 141,1$ milhões. No entanto, em 2003 os empreendimentos de comércio receberam 91\% dos recursos do CrediAmigo. 1

As indústrias receberam $4 \%$ dos recursos, enquanto o segmento dos serviços ficou com 5\%. Em 2004 o CrediAMIGO aumentou sua participação no mercado potencial de microempreendedores o comércio recebeu $92 \%$ dos recursos do CrediAmigo.

As indústrias receberam $3 \%$ dos recursos, enquanto o segmento dos serviços ficou com 5\%, esses números permaneceram até 2006. Os clientes são, em sua maioria, pessoas que trabalham por conta própria, em negócios de pequeno porte, e se caracterizam por dispor de um mínimo de capital fixo, utilizam poucos trabalhadores - familiares ou assalariados, registrados ou não - e por participar diretamente da atividade comércial recebeu $92 \%$ dos recursos do CrediAmigo. 
As indústrias receberam $2 \%$ dos recursos, enquanto o segmento dos serviços ficou com $6 \%$, esses foram os valores de 2007 . São pequenas unidades produtivas que nasceram como alternativa de fonte de renda para seus proprietários. Além de utilizarem pequena quantidade de trabalhadores assalariados, dispõem de poucos capitais fixos, apresentam ampla necessidade de capital de giro e não têm acesso ao mercado formal de crédito. Assim em 2008 os recursos foram destinados $92 \%$ para o comércio, $3 \%$ para indústria e $5 \%$ para serviços. Em 2009, os recursos para a indústria foram menores de toda a série apenas $1 \%$, os demais $93 \%$ para comercio e $6 \%$ para serviços.

Em 2010, mais de 1,5 milhão de empreendedores tiveram a chance de encontrar um novo caminho para seus negócios, por meio de acesso ao crédito, a serviços financeiros e orientação profissional, assim o crédito no ano de 2010 destinados $92 \%$ para o comércio, $2 \%$ para a indústria e $6 \%$ para o segmento de serviços.

j) Escolaridade;

Tabela 11

\begin{tabular}{|r|r|r|r|r|r|}
\hline & SUPERIOR & $\begin{array}{l}\text { DE 9 A 11 anos } \\
\text { de estudo } \\
\text { formal }\end{array}$ & $\begin{array}{l}\text { DE 5 A 8 de } \\
\text { estudo formal }\end{array}$ & $\begin{array}{l}\text { ATÉ 4 de } \\
\text { estudo } \\
\text { formal }\end{array}$ & ANALFABETO \\
\hline $\mathbf{2 0 0 0}$ & $3 \%$ & $31 \%$ & $15 \%$ & $46 \%$ & $5 \%$ \\
\hline $\mathbf{2 0 0 1}$ & & & & & \\
\hline $\mathbf{2 0 0 2}$ & & & & & \\
\hline $\mathbf{2 0 0 3}$ & & & $16 \%$ & $50 \%$ & $3 \%$ \\
\hline $\mathbf{2 0 0 4}$ & $3 \%$ & $28 \%$ & $29 \%$ & $38 \%$ & $3 \%$ \\
\hline $\mathbf{2 0 0 5}$ & $3 \%$ & $29 \%$ & $28 \%$ & $37 \%$ & $1 \%$ \\
\hline $\mathbf{2 0 0 6}$ & $3 \%$ & $29 \%$ & $30 \%$ & $34 \%$ & $2 \%$ \\
\hline $\mathbf{2 0 0 7}$ & $4 \%$ & $31 \%$ & $28 \%$ & $33 \%$ & $4 \%$ \\
\hline $\mathbf{2 0 0 8}$ & $4 \%$ & $33 \%$ & $28 \%$ & $32 \%$ & $31 \%$ \\
\hline $\mathbf{2 0 0 9}$ & $4 \%$ & $34 \%$ & $28 \%$ & & \\
\hline $\mathbf{2 0 1 0}$ & $4 \%$ & $32 \%$ & & & \\
\hline
\end{tabular}

Fonte: Relatórios do CrediAmigo de 2000 a 2010 
Gráfico 10

\section{ESCOLARIDADE CREDIAMIGO}

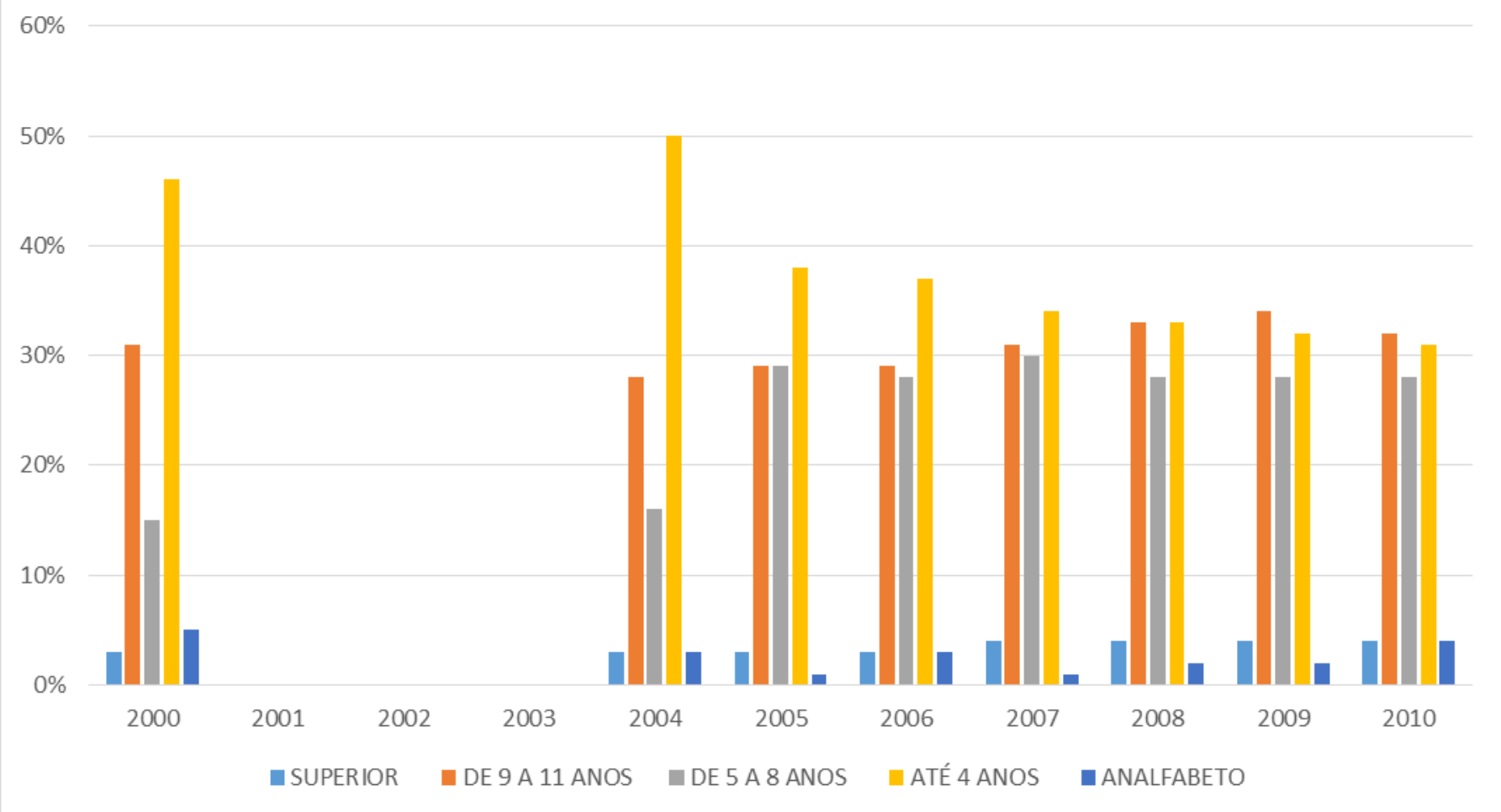

Fonte: Relatórios do CrediAmigo de 2000 a 2010

No ano 2000, no que diz respeito à educação os clientes do programa CrediAmigo refletem um triste dado da nossa sociedade brasileira analfabeta ou com $1^{\circ}$ grau incompleto somavam $61,7 \%$ no interior, $53,8 \%$ na região metropolitana e 59,6\% somavam de todo o Programa.

Entre os anos 2001 a 2003 essas informações não constavam nos relatórios e BNB não dispunha dos dados em contato por e-mail. Do total de clientes do CrediAmigo em 2004 os dados da escolaridade mostram 3\% com nível superior $28 \%$ de 8 a 11 anos de permanência na escola $16 \%$ de 5 a 8 anos de tempo na escola $50 \%$ até 4 anos de permanência na escola e $3 \%$ analfabetos. Entre os anos de 2005 até 2010 os dados permaneceram praticamente inalterados. 
k) Renda familiar

Tabela 12

\begin{tabular}{|r|r|r|r|r|r|}
\hline ANO & ATÉ R\$ 600 & $>\mathrm{R} \$ 600<\mathrm{R} \$ 1000$ & $\begin{array}{l}\text { 1 R\$ } 1000<\mathrm{R} \$ \\
1500\end{array}$ & $\begin{array}{l}\text { > R\$ } 1500<\mathrm{R} \$ \\
5000\end{array}$ & \multicolumn{2}{l|}{$\begin{array}{l}\text { ACIMA DE R\$ } \\
5000\end{array}$} \\
\hline 2003 & $36 \%$ & $26 \%$ & $16 \%$ & $20 \%$ & $2 \%$ \\
\hline 2004 & $30 \%$ & $28 \%$ & $18 \%$ & $21 \%$ & $3 \%$ \\
\hline 2005 & $29 \%$ & $28 \%$ & $18 \%$ & $22 \%$ & $3 \%$ \\
\hline 2006 & $31 \%$ & $29 \%$ & $18 \%$ & $20 \%$ & $2 \%$ \\
\hline 2007 & $32 \%$ & $27 \%$ & $17 \%$ & $21 \%$ & $3 \%$ \\
\hline 2008 & $31 \%$ & $28 \%$ & $16 \%$ & $22 \%$ & $3 \%$ \\
\hline 2009 & $34 \%$ & $26 \%$ & $21 \%$ & $16 \%$ & $3 \%$ \\
\hline 2010 & $37 \%$ & $24 \%$ & $15 \%$ & $20 \%$ & $3 \%$ \\
\hline
\end{tabular}

Fonte: Relatórios do CrediAmigo de 2000 a 2010

\section{Gráfico 11}

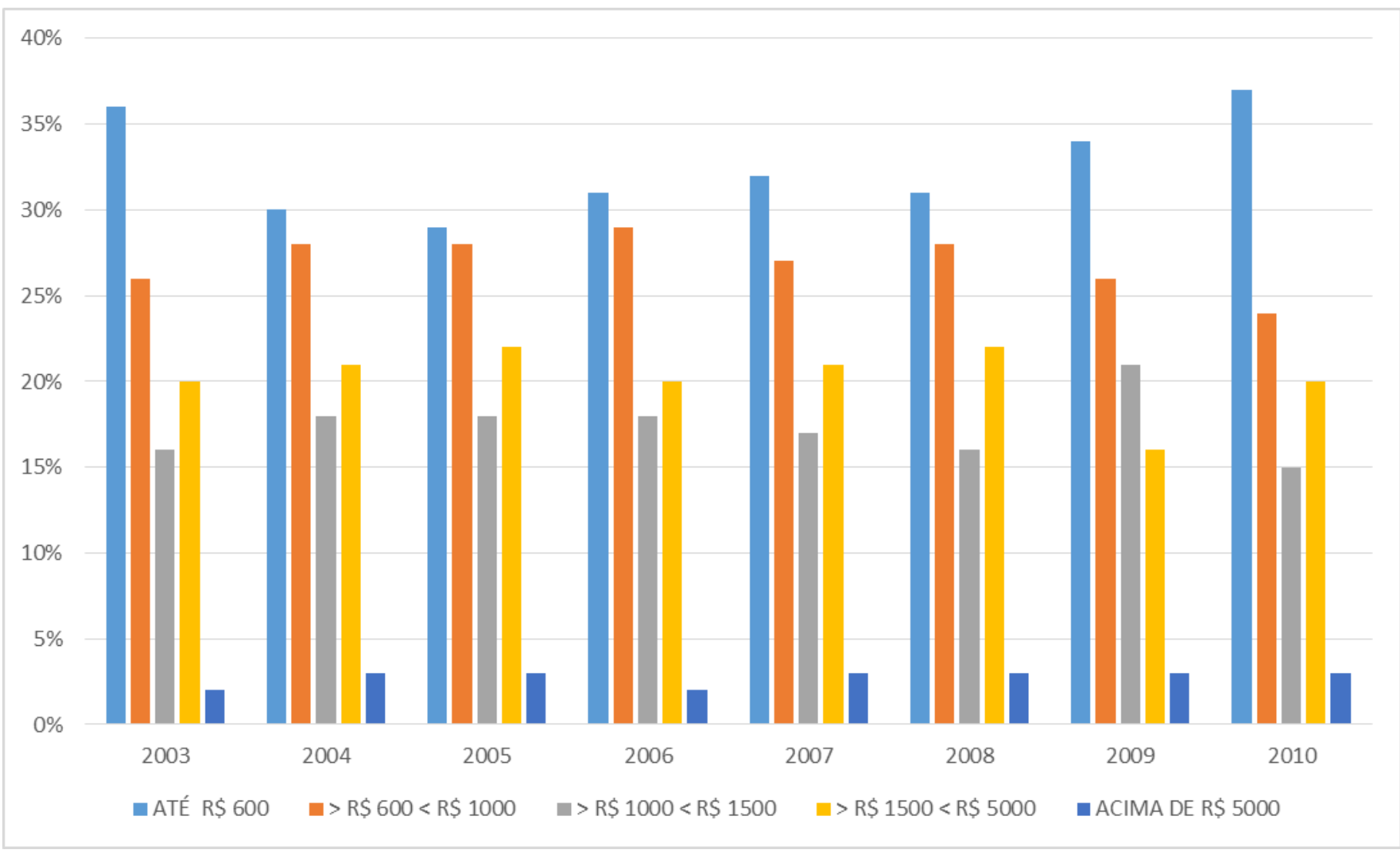

Fonte: Relatórios do CrediAmigo de 2003 a 2010

O retorno ao crescimento sustentável só tende a favorecer a camada da população de baixa renda e a gerar uma ambiência favorável ao desenvolvimento 
das microfinanças. Alguns fatores contribuem positivamente para o aumento da renda dos microempresários nordestinos.

É o caso da educação, cada ano de estudo corresponde a um aumento de $3,34 \%$ na renda do associativismo e cooperativismo os empreendedores que se associam apresentam um lucro 39,62\% maior que os donos únicos de negócios e da formalização do empreendimento. A renda dos que se constituem juridicamente supera a dos que atuam no setor informal em 15,9\%.

A localização do microempreendimento também influi no desempenho, resultando em lucro $11,27 \%$ maior para aqueles situados na região metropolitana. Entre 2003 a 2004, de acordo com o porte, os clientes do CrediAmigo podem-se dizer que a maioria das famílias até $30 \%$ ganhando até $\mathrm{R} \$ 600,00$ fica em situação de subsistência.

Entre 2006 e 2010 os valores são praticamente os mesmos com renda até $R \$ 600$, entre 2007 e 2010 os clientes que ganhavam acima de $R \$ 5.000$ se apresentou inalterado.

I) Idade

\section{Tabela 13}

\begin{tabular}{|c|c|c|c|c|}
\hline Ano & $\begin{array}{c}\text { Entre 18 e 24 } \\
\text { anos }\end{array}$ & $\begin{array}{c}\text { Entre 25 e 35 } \\
\text { anos }\end{array}$ & $\begin{array}{c}\text { Entre 36 e 50 } \\
\text { anos }\end{array}$ & $\begin{array}{c}\text { Acima de 50 } \\
\text { anos }\end{array}$ \\
\hline 2000 & $8 \%$ & $31 \%$ & $44 \%$ & $8 \%$ \\
\hline 2001 & $11 \%$ & $31 \%$ & $43 \%$ & $15 \%$ \\
\hline 2002 & $9 \%$ & $31 \%$ & $44 \%$ & $16 \%$ \\
\hline 2003 & $9 \%$ & $31 \%$ & $42 \%$ & $18 \%$ \\
\hline 2004 & $7 \%$ & $30 \%$ & $45 \%$ & $18 \%$ \\
\hline 2005 & $11 \%$ & $31 \%$ & $40 \%$ & $18 \%$ \\
\hline 2006 & $11 \%$ & $31 \%$ & $40 \%$ & $18 \%$ \\
\hline 2007 & $12 \%$ & $31 \%$ & $39 \%$ & $18 \%$ \\
\hline 2008 & $9 \%$ & $31 \%$ & $42 \%$ & $18 \%$ \\
\hline 2009 & $9 \%$ & $32 \%$ & $41 \%$ & $18 \%$ \\
\hline 2010 & $13 \%$ & $32 \%$ & $37 \%$ & $18 \%$ \\
\hline
\end{tabular}


Fonte: Relatórios do CrediAmigo de 2000 a 2010

\section{Gráfico 12}

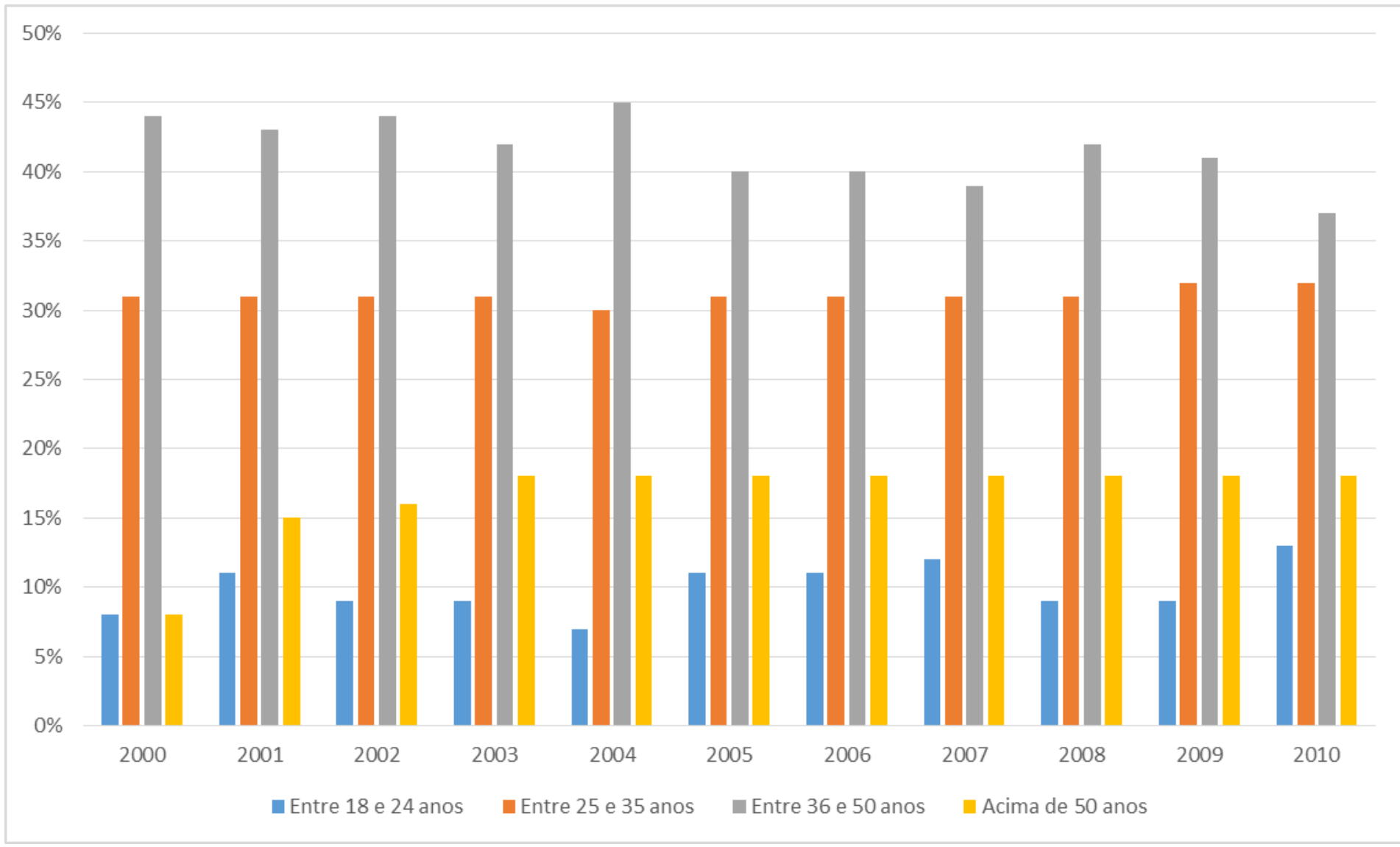

Fonte: Relatórios do CrediAmigo de 2000 a 2010

No ano de 2000, os clientes do CrediAmigo nas regiões metropolitanas e no interior dos Estados apresentavam características distintas conforme a localização acima de 35 anos $57,5 \%$ no interior, $62,4 \%$ região metropolitana e $59,1 \%$ em todo o Programa.

O perfil dos clientes do CrediAmigo praticamente não variou entre $2000 \mathrm{e}$ 2001. Em 2002, 60\% dos clientes tinha idade superior a 36 anos. Em 2003, tinha idade superior a 36 anos, dos quais 18\% têm mais de 50 anos, faixas etárias de difícil colocação no mercado de trabalho.

Forte instrumento de fortalecimento da cidadania e de redução das desigualdades sociais na Região Nordeste do Brasil, o CrediAmigo proporciona a inserção competitiva dos microempreendedores no mercado, contribuindo para fortalecer e ampliar suas atividades, aumentar seus ganhos financeiros e melhorar a 
qualidade de vida de suas famílias. Entre os anos de 2003 até 2010 os números mudaram e $18 \%$ dos clientes por terem mais de 50 anos mostram a importância do Programa para a população mais idosos.

Outra parcela que ficou praticamente inalterada entre 2000 até 2010 foi a faixa entre 25 e 35 anos de idade. 


\section{CONCLUSÃo}

O Brasil desde os anos 2000 até os dias atuais vem passando por diversas mudanças tanto no aspecto econômico quanto no social. A pesar da analise deste estudo se refere somente aos anos de 2000 a 2010, os aspectos nas mudanças sociais efetivamente pelos governos começaram a ter uma ênfase maior a partir da década de $90 \mathrm{com}$ a criação do Plano Real para conter a inflação. Nesse período podemos perceber que era latente a desigualdade social e econômica e que já existia uma preocupação muito forte por parte dos governantes.

Nesse sentido foi percebida por parte dos governantes a necessidade de implementação de políticas públicas para de certa forma tentar diminuir tanto a pobreza quanto o desemprego no país.

Assim, percebemos a grande importância das políticas de microcrédito como facilitador, e apesar das políticas terem começado no Governo de Fernando Henrique Cardoso elas ganharam força no Governo de Lula, onde as camadas mais pobres da sociedade começaram a fazer parte das políticas prioritárias do Governo Federal.

Nesse aspecto as políticas de microcrédito contribuíram e contribuem até hoje como um grande instrumento de redução da pobreza e desigualdade social.

Destarte, por meio de estudos conseguimos analisar a política do CrédiAmigo desde $\mathrm{o}$ ano de 2000 até 2010 e percebemos com esse recorde que com a retomada da economia brasileira no ano de 2000 o CrediAmigo pôde aplicar mais recursos que nos dois anos inicias de atividades.

Segundo demonstram os relatórios do Programa foram aplicados $\mathrm{R} \$ 125.9$ milhões investidos em 165,9 mil operações de empréstimos à população de baixa renda.

Por conseguinte, o Programa CrediAmigo consolidou a liderança de mercado registrando crescimento em torno de $87,9 \%$ de sua carteira ativa e 57,9 mil beneficiários ativos no mês de dezembro. Por meio desse crescimento tornou possível a criação de mais 35 agências e cinco postos de atendimento, além de 
contratados e capacitados 92 novos assessores que passaram a integrar a equipe de trabalho, aqui ela já atendia em 2000358 cidades.

Ou seja, em uma época em que o nosso país tinha um índice de desemprego muito alto, o programa conseguia crescer de forma a gerar emprego e renda para a população, sobretudo a de baixa renda.

Com o grande crescimento do programa foi possível efetuar o contrato no valor de U\$\$ 50 milhões junto ao Banco Mundial. E devido ao seu destaque de crescimento, tornou possível seu reconhecimento no IV congresso de Inovação na Gestão Pública Federal, promovida pela Escola Nacional de Administração Pública ENAP, Mistério do Planejamento e o Instituto Hélio Beltrão.

Esse Programa foi também contemplado como destaque de desburocratização, também pelo Instituto Hélio Beltrão. O CrediAmigo proporciona um tratamento ágil e personalizado aos seus clientes, com atendimento no próprio empreendimento do tomador.

Ele também, constitui um modelo de gestão baseado na sustentabilidade, com profissionais contratados no mercado, o que gerou uma estrutura de custos flexíveis, assim ele é autossustentável, e apesar de contribuir no aspecto social não é um modelo assistencialista e não prega esse sistema.

Remunera os capitais investidos com regras de mercado, cobrindo os custos de sua operacionalização, incluindo a depreciação de ativos fixos, com provisão para perdas por empréstimos, riscos operacionais e custo financeiro.

Dessa forma, a continuidade do Programa é garantida independente de fontes subsidiadas, orçamento governamental ou quaisquer doações internacionais. Esse talvez seja um de seus melhores pontos positivos.

O seu processo metodológico possibilita acesso rápido ao crédito, com transcurso máximo de sete dias para liberação dos recursos e os valores dos empréstimos podem evoluir gradualmente, com um limite de 50\% de aumento em relação a operação anterior. 
O programa ainda incentiva os tomadores como forma de premiação de $15 \%$ de desconto nos juros por ocasião do pagamento da última parcela do empréstimo.

Esse programa apresenta vários pontos positivos, como maior índice de penetração de mercado por exemplo na região Nordeste, ele é responsável por 57,9 mil clientes ativos em dezembro de 2000. Assim como a sua capilaridade de sua estrutura em sua rede de agência e postos de atendimentos que permitem o atendimento com as devidas orientações aos clientes do Banco com acesso à tecnologia de crédito.

Além disso é disponibilizado também aos clientes assessoria, por meio de visitas previamente a aquisição do crédito, onde são passadas as informações sobre a capacitação desses clientes por meio de treinamentos por módulos que abrangem temas relacionados à gestão empresarial, financeira, ambiental assim como sobre à modernização tecnológica e comercialização.

O CrediAmigo criou um sistema de informações específicos para fornecer os dados relativos à parceria com o Banco Mundial.

No ano de 2001 as aplicações do CrediAmigo no setor microempresarial do Nordeste somaram, em 2001, R\$ 201 milhões em 257,8 mil operações de crédito. Nesse sentido, sem concorrentes do mesmo porte, o programa de crédito popular do Banco do Nordeste findou o ano de 2001 como maior responsável pela penetração de mercado de $4,6 \%$ no Nordeste - o maior índice verificado entre as regiões brasileiras.

O impacto positivo das ações do CrediAmigo pôde ser verificado através de uma pesquisa realizada pelo Instituto de Pesquisas Sociais e Econômicas (IPESP), que atestou um índice de satisfação como o Programa superior a $90 \%$ entre seus beneficiários.

Um resultado positivo também confirmado através de uma auditoria realizada pelo Tribunal de Contas da União-TCU na Paraíba aferiu sua efetividade do programa. Em seu parecer, a auditoria do TCU, afirma que "a análise mais aprofundada da matéria principalmente junto ao público-alvo na constatação de que 
de modo geral, o programa vem efetivamente beneficiando sua clientela, se não na aplicação dos negócios, ao menos na sua manutenção. "

$\mathrm{Na}$ pesquisa realizada pelo TCU, $93 \%$ dos clientes ativos confirmaram a facilidade para obter os empréstimos, item que só perde para os juros baixos entre as principais vantagens do CrediAmigo apontadas pelos clientes.

A maioria absoluta (93\%) dos que deixaram o programa o recomendaria a outros microempresários e quase todos (98\%) afirmaram que estão satisfeitos com a ajuda do assessor de crédito.

As ações tiveram da Agência Alemã de Investimento (DEG) que, assinou contrato com o Banco do Nordeste no valor de 15 milhões de euros para o financiamento da carteira de empréstimos do programa.

Os empréstimos ofertados pelo programa giram em torno de $\mathrm{R} \$ 100,00$ até $R \$ 1.000,00$, sendo que esse valor pode chegar até $R \$ 15.000,00$. E apesar do volume de empréstimos serem altos a taxa de inadimplência do CrediAmigo tem tido, ao logo de sua existência um comportamento acentuado de queda, chegando ao índice de 0,84\%, no ano de 2004, de acordo com os relatórios anuais do Banco.

No ano de 2005 em sua terceira edição do Prêmio de Microcredito do BNB, que tem por objetivo reconhecer as iniciativas de sucesso dentre os clientes do CrediAmigo com títulos de capitalização no valor de $\mathrm{R} \$ 700,00$ e troféus.

Com o objetivo de motivar os clientes a valorizar as instituições microfinanceiras o Citibank, juntamente com a Accion Internacional, criou o Prêmio Citigroup-Accion. Os candidatos concorreram em três categorias: comércio, indústria e serviços, e pelo segundo ano consecutivo, os clientes do Crediamigo foram agraciados com os prêmios dentre as principais instituições de microcrédito do País.

Nesse sentido, pode-se perceber que a eficiência operacional vem apresentando crescimento contínuo com o aumento de produtividade, atingindo a média de 402 clientes/assessor de negócio em dezembro de 2006. Assim podemos perceber que o programa desenvolve várias ações como por exemplo em seu programa Educando para Desenvolver que teve início no ano de 2006 com o 
objetivo de reduzir o índice de analfabetismo dos clientes do CrediAmigo (dos quais $38 \%$ de um universo de aproximadamente 235 mil clientes em 2006, o Prêmio Melhores Microempreendedores, do Citigroup Brasil, quando dos nove vencedores, seis foram do CrediAmigo.

Assim, percebe-se que desde $1998 \mathrm{com}$ a abertura 45 unidades o programa foi crescendo a cada ano de maneira a beneficiar a camada mais pobre do nosso país, não somente no Nordeste, tendo em vista que podemos citar como exemplo a parceria no Rio de Janeiro com o VivaCred.

Outro importante reconhecimento feito ao Programa CrediAmigo, foi o reconhecimento conferido ao INEC, eleito uma das 150 melhores empresas para se trabalhar no Brasil, segundo a Gui Você S/A - Exame 2009, celebrando uma vitória construída como fruto da parceria com o Banco do Nordeste.

Todavia, é importante ressaltar que o Programa tem contribuído e muito para a redução da pobreza e desigualdade em nosso país. Isto posto com relação ao desenvolvimento na indústria de microfinanças se comparado a outros países, o Brasil ainda está atrasado, com exceção do programa CrediAmigo do Banco do Nordeste, os demais bancos que trabalham com as políticas de microcrédito encontram-se em atraso seja pelas altas taxas cobradas ou seja pelos entraves burocráticos, sem falar nas garantias reais que a grande maioria as instituições exigem dos pequenos empreendedores.

Assim, o Programa CrediAmigo de certa forma funciona como um facilitador no auxilio e fornecimento de crédito aos empreendedores de baixa renda que não possuem acesso às linhas de crédito tradicional. Portanto, o empenho realizado pelas políticas do CrédiAmigo vem sendo fundamental na estimulação voltada para ações que viabilizam o acesso ao crédito das pessoas de baixa renda.

Contudo, mesmo com essas ações e juntamente com as ações de estímulos por parte do Governo Federal que incentiva outras instituições no fornecimento de crédito, ainda necessitam de melhorias em sua disponibilização às pessoas que realmente necessitam deste crédito. 
A pesquisa desta dissertação foi baseada em pesquisa bibliográfica de vários autores, assim como detalhada de acordo com os relatórios anuais da década de 2000 até 2010, do Programa CrediAmigo, disponibilizados pelo Banco do Nordeste. Tendo como objetivo desta pesquisa em responder por meio desta dissertação as contribuições do Programa Crediamigo como forma de inclusão social e econômica, de maneira que isso irá refletir na redução da pobreza por meio da inclusão e geração de emprego e renda.

Diante de todo estudo, podemos evidenciar que o Programa CrediAmigo, oferta crédito aos pequenos e microempreendedores de baixa renda que apesar da quantia ofertada individualmente ser de baixo valor, pôde ser percebido por meio deste estudo que ao juntar todas as operações ofertadas pelo programa geram um impacto positivo muito grande na economia do país gerando emprego e renda e consequentemente a inclusão social e econômica das pessoas de baixa renda.

Foi demostrado nesse trabalho, também que a maioria as operações ofertadas ao Programa estão voltadas para pequenas atividades tais como: comercialização de confecção, frutas, verduras e outras atividades simples.

Por meio dessa pesquisa, também foi possível perceber que a grande concentração dos clientes de baixa renda que utilizam o CrediAmigo encontram-se no Nordeste.

Não podemos afirmar que as políticas de microcrédito são as únicas a refletirem na melhoria de vida dessas pessoas de baixa renda, porém é importante ressaltar que essas políticas certamente desempenham um papel muito importante em nossa economia.

Assim, conclui-se que a partir dos objetivos proposto nesta pesquisa, foi possível perceber que o programa CrediAmigo é um importante agente que vem ao longo dos anos ajudando os pequenos empreendedores do nosso país em especial os do nordeste de maneira que após o estudo percebemos também que ele vem incentivado as pessoas de baixa renda a buscarem melhores condições de vida e, apesar do Programa mesmo com suas benesses contribuírem para a melhoria de 
vida, ele por si próprio não é capaz de consegui resolver o problema da pobreza em nosso país. 


\section{REFERÊNCIAS BIBLIOGRÁFICAS:}

AGÊNCIA NACIONAL DE DESENVOLVIMENTO MICROEMPRESARIAL.

Perguntas Microfinanças. Disponível em:

$<$ http://www.agenciaande.org.br/site/paginaTexto.php?c=66>. Acesso em: 12 jun. 2016.

ALVES, Micheline. Uma nova lógica. 2015. Disponível em:

<http://revistatrip.uol.com.br/trip/o-banqueiro-dos-pobres-muhammad-yunuspropoe-uma-nova-logica>. Acesso em: 10 jun. 2016.

BANCO DO NORDESTE. Crediamigo. Disponível em: <http://www.bnb.gov.br/crediamigo>. Acesso em: 8 jun. 2016.

BANCO DO NORDESTE. Relatório 2013: Programas de Microfinanças do Banco do Nordeste. 2014.

BANCO INTERNACIONAL DE DESENVOLVIMENTO (BID). Microfinance enters commercial mainstream in Brazil. Disponível em: <http://www.ibd.org>. Acesso em: 10 jun. 2016.

BANCO MUNDIAL. Pobreza y desarrollo social, Washington D.C. 1999.

BARONE, Francisco Marcelo et al. Introdução ao microcrédito. Brasília: Conselho da Comunidade Solidária, 2002.

BICHIR, R. M. Analisando a porta de entrada aos programas de transferência de renda: São Paulo e Salvador. Bahia Análise \& Dados, v. 19, p. 993-1008, 2010.

CONFEDERAÇÃO NACIONAL DA INDÚSTRIA (CNI). Pesquisa CNI-IBOPE: Retratos da Sociedade Brasileira: Inclusão Financeira. Brasília: Confederação Nacional da Indústria, 2012. 94 p.

COSTA, Fernando Nogueira. Microcrédito no Brasil. Texto para Discussão IE/UNICAMP, Campinas, n. 175, nov. 2010.

D'AMORIM, Sheila. Governo reedita ação de estímulo ao microcrédito. 2011. Disponível em: <http://www1.folha.uol.com.br/fsp/poder/po2508201119.htm>. Acesso em: 3 jun. 2016.

FERREIRA, Aurélio Buarque de Holanda. Novo dicionário da língua portuguesa. 2. ed. Rio de Janeiro: Editora Nova Fronteira, 1986. 
INSTITUTO BRASILEIRO DE ADMINISTRAÇÃO MUNICIPAL — IBAM. Programa Gênero e Políticas Públicas: Informações básicas. Rio de Janeiro: IBAM, 2011.

INSTITUTO DE PESQUISA ECONÔMICA APLICADA. A Década Inclusiva (2001-2011): Desigualdade, Pobreza e Políticas de Renda. Comunicados do Ipea, Brasília, n. 155, set. 2012.

LAVINAS, Lena. Transferências de Renda: o quase tudo do sistema de proteção social brasileiro. In: SICSÚ, João. (Org.). Arrecadação, de onde vem? E Gastos Públicos, para onde vão? São Paulo: Boi Tempo Editora e Instituto Rosa Luxemburgo, 2007.

LAVINAS, Lena. Transferências de Renda: o quase tudo do sistema de proteção social brasileiro. In: SICSÚ, João. (Org.). Arrecadação, de onde vem? E Gastos Públicos, para onde vão? São Paulo: Boi Tempo Editora e Instituto Rosa Luxemburgo, 2007.

MATOS, F.; CACCIAMALI, M. C.; MACAMBIRA, J. (orgs) A Atividade e a Política de Microcrédito no Brasil: visões sobre sua evolução e futuros desafios. Fortaleza: IDT, USP, 2014.

MATOS, Franco de. Avaliação comparativa das atividades de microcrédito Brasil e Bolívia. 2002. 111f. dissertação de Mestrado - Programa de Integração da América Latina - PROLAM/USP. São Paulo. 2002

Mazzutti, C. Microfinanças no Brasil: afinal, existe um trade-off entre o foco na pobreza e a sustentabilidade financeira? Dissertação de mestrado, Universidade Federal do Rio Grande do Sul, Porto Alegre, 2005.

NÉRI, M.C. Miséria, desigualdade e política de renda: O Real de Lula. Sumário executivo: Rio de Janeiro: FGV/IBRE, CPS, 2007.

NERI, Marcelo. (org). Microcrédito: o mistério nordestino e o Grameen brasileiro. Perfil e performance dos clientes do Crediamigo. Rio de Janeiro: FGV, 2008

OTERO, M. Twenty Years of Microfinance and Future Challenges. V INTERNATIONAL FORUM ON MICROENTERPRISE. Anais... Rio de Janeiro:IADB, 2002.

PIETRO, Maria Sylvia Zanella Di. Direito administrativo. 14. ed. São Paulo: Editora Atlas, 2002.

PIMENTEL, Lopes Janaine. Políticas de microfinanças: Análise da atuação das cooperativas de crédito no Brasil e na Bolívia.2009. 34f. dissertação de Mestrado - 
Programa em integração da América Latina - PROLAM/USP. 2009

PRAHALAD, C. K. A riqueza na base da pirâmide: como erradicar a pobreza com o lucro. Porto Alegre: Bookman, 2005.

SACCONI, Luiz Antônio. Gramática essencial da língua portuguesa, 5. ed., rev. São Paulo: Atual, 1989.

SEN, Amartya. Desenvolvimento como liberdade. São Paulo: Companhia das Letras, 2007.

SINGER, Paul. Globalização e desemprego: diagnóstico e alternativas. 4. ed. São Paulo: Contexto, 2000.

SOARES, Marden Marques; MELO SOBRINHO, Abelardo Duarte. Microfinanças: o papel do Banco Central do Brasil e a importância do cooperativismo de crédito. Brasília: BCB, 2008. 202 p.

SOARES, Marden Marques; SOBRINHO, Abelardo Duarte de Melo. Microfinanças: o papel do Banco Central do Brasil e a importância do cooperativismo de crédito. Brasília: BCB, 2008.

SOUZA, Maria Célia Garcia Ferreira. Avaliação do desenho do Programa Crediamigo do Banco do Nordeste: inclusão social e mercado. Dissertação de Mestrado. Fortaleza: UFC, 2008

TUCKER, Jeffrey. Por que o microcrédito não pode salvar o mundo. 2009. Disponível em: <http://www.mises.org.br/Article.aspx?id=442>. Acesso em: 1 jun. 2016.

VOLPON, Tony. A Globalização e a Política: de FHC a Lula. Rio de Janeiro: Revan, 2003.

WIKIPEDIA. Governo Dilma Rousseff. Disponível em:

$<$ https://pt.wikipedia.org/wiki/Governo_Dilma_Rousseff>. Acesso em: 2 jun. 2016.

XALUAN. O surgimento do Microcrédito no Brasil. 2008. Disponível em: $<$ https://economiaparapoetas.wordpress.com/2008/07/26/o-surgimento-domicrocredito-no-brasil/>. Acesso em: 10 jun. 2016.

YUNUS, Muhammad. O banqueiro dos pobres. São Paulo: Editora Ática, 2006.

ZOUAIN, Deborah Moraes. Excertos sobre política pública de acesso ao crédito como ferramenta de combate à pobreza e inclusão social: o microcrédito na era 
FHC. Small Business através do panóptico. Revista de Administração Pública RAP. Rio de Janeiro: FGV/EBAPE, 2007. 